\title{
Approaches in Research on Flood Risk Perception and Their Importance in Flood Risk Management
}

\author{
Ewa Lechowska ( $\square$ ewaglo@amu.edu.pl ) \\ Uniwersytet im Adama Mickiewicza w Poznaniu https://orcid.org/0000-0003-2588-1206
}

\section{Research Article}

Keywords: flood, risk perception, factor, rationalist approach, constructivist approach, resilience.

Posted Date: March 15th, 2021

DOI: https://doi.org/10.21203/rs.3.rs-214525/v1

License: (a) (i) This work is licensed under a Creative Commons Attribution 4.0 International License. Read Full License 


\section{Abstract}

The study of flood risk perception factors can be considered by using different paradigms. In attempting to understand risk perception, two basic paradigms can be distinguished: rationalist and constructivist. The rationalist approach tends to focus on modeling, characterizing, and predicting behavioral results regarding various threats. According to the constructivist paradigm, threats are perceived as socially constructed.

This paper aims to assess the importance of the rationalist and constructivist approaches in research on flood risk perception and flood risk management more broadly by answering the questions: (1) which factors are more effective in moderating attitudes towards flood risk?, (2) which research approach provides more useful information in shaping attitudes towards flood risk?, (3) research in which approach provides more useful information to improve flood risk management? The paper concludes by pointing out the desired direction of research on flood risk perception from the perspective of improving flood risk management.

In contemporary empirical works managing the perception of flood risk, a rationalistic approach that psychometrically searches for cognitive models dominates. Often, statistically obtained dependencies are mutually exclusive. Thus, studies on perception that apply the constructivist approach are in an early stage of development. They indicate that the social, political, cultural, religious, and historical contexts shape the perception of flood risk. On the basis of the aforementioned information, the focus of research on flood risk should shift to studies conducted by applying the constructivist approach, highlighting the role of contextual factors in shaping risk perception.

\section{Introduction}

Traditional approaches to flood risk management that focus on physical flood protection or improvements in flood monitoring and forecasting have tended to overlook the social dimensions of floods, such as the public's understanding of risk. Today, flood perception is recognized as a key factor in developing effective flood management strategies. How people perceive and understand flood risk affects the actions they take to prepare for and respond to flood events.

Motivated by many goals, orientations, and research interests, the studies of flood risk perception have presented a heterogeneous picture. Perception research has been conducted by researchers from various fields of science, resulting in a discrepancy in the basic theoretical issues (even the definition of risk), a different way of formulating a research problem, and the diversity of applied methods.

Bubeck et al. (2012) and Kellens et al. (2013) have stated, based on a literature review on the perception of flood risk, that there is no basic theoretical framework available within the social sciences. This work aims to fill this gap and strengthen the theoretical basis of the research on the perception of flood risk distinguishing on the grounds of epistemology two basic paradigms - rationalist and constructivist. However, these paradigms are not dichotomous (absolute). Their distinction is aimed at highlighting heterogeneity in the field of flood risk perception research-discrepancies in applied approaches. The terms rationalist and constructivist have epistemic connotations, which cannot be simply characterized by methodological approaches that would be strictly pertinent to one or the other epistemology.

The aim of this paper is to answer the questions:

- Which factors are more effective in moderating attitudes towards flood risk?,

- Which research approach provides more useful information in shaping attitudes towards flood risk?

- Research in which approach provides more useful information to improve flood risk management?

The relevance of rationalist and constructivist approaches in the study of flood risk perception and flood risk management more broadly was assessed through:

1. explore, how the substantive scope of research on flood risk perception factors in the context of applied paradigms has evolved by proposing the categorization of the studied factors according to their character and applied research approach;

2. determining the interrelationships between the various factors of a rationalist and constructivist nature (and between the paradigms more broadly) by comparing the results of research conducted in the two distinguished research streams;

3. determining the role of rationalist and constructivist factors in shaping attitudes towards flood risk.

The culmination of the purpose of this paper is to indicate the desired direction of flood risk perception research from the perspective of improving flood risk management.

Many studies have listed the factors that may influence flood risk assessment, but none considers the issue in the context of assessing the importance of rationalist and constructivist approaches to flood risk management. Most of the reviews have focused on identifying predictors of adaptive behavior to mitigate flood risks (Bubeck et al. 2012, Koerth et al. 2017, Bamberg et al. 2017, van Valkengoed, Steg 2019, Kellens et al. 2013). Some have only considered one type of flood risk perception factor (Bradford et al. 2012, Kellens et al. 2013, Wachinger et al. 2013) or the spatial scope of the analyses has been strictly limited in terms of the territory (Raska 2015). Few studies have compared the research results of risk perception in a transnational perspective (e.g., Boholm 1998). There is also a lack of reviews that have addressed the issue from a constructivist or rationalistic perspective. Brikholz et al. (2014) show how useful these approaches are' however, the authors focus on the perception of flood risk as part of a broader risk management system and do not analyze the factors influencing the assessment of flood risks exclusively. This article therefore attempts to fill this research gap. 
The phenomenon of underestimation of flood risk has been observed, which represents an important challenge for flood risk management. The knowledge of factors influencing the perception of flood risks is critical in practical terms because it allows the development of a risk communication strategy, increasing the resilience of the population to flood risks.

The paper is divided into sections reflecting the logical sequence of the research. The introduction describes the significance of the issue being addressed and the purpose of the research. The second section is devoted to characterizing the rationalist and constructivist approaches. The next third presents the classifications of flood risk perception factors available in the literature. The fourth section describes the research method in detail, including the thought pattern, briefly characterizes the selected empirical studies and classifies the flood risk perception factors according to the research streams. The fifth part is devoted to the results of the research, more specifically, to presenting the evolution of the substantive scope of the factors of flood risk perception, then, by comparing the results of the research conducted in the two distinguished research streams, to determining the interrelationship between the various factors of a rationalist and constructivist nature (and more broadly between the paradigms). In the final part of the sixth part, the conclusions and discussion identify the role of rationalist and constructivist factors in shaping attitudes towards flood risk, assess the significance of rationalist and constructivist approaches in research on the perception of flood risk and more broadly in flood risk management. The paper concludes by indicating the desirable direction of flood risk perception research from the perspective of improving flood risk management.

\section{Rationalist And Constructivist Paradigm}

The rationalist approach to risk perception stresses individual cognitive processes and assumes that the existence of a threat induces an individual to make an assessment or judgment that feeds a "rational" decision-making process regarding the need to adopt a protective or preventive behavior. Studies rooted in the rationalist approach have tended to focus on modeling, characterizing, and predicting behavioral results regarding various threats. Such substantive approaches, for example, limited rationality and protection motivation theory, are largely rooted in the rationalist paradigm (closely related to cognitive psychology) and reveal the complex dependence of factors that can influence decision-making regarding protection against flood risk (Birkholtz et al. 2014) (Fig. 1). The rationalist paradigm assumes that individual risk preferences and behavioral results are the effects of a logical assessment of the likely outcomes, as well as related costs and benefits. In this context, the rationalist paradigm provides information on many algorithms shaping the decisionmaking process when there is risk. In the conventional rationalist paradigm, we observe how society assesses the costs and benefits of living in the affected areas (White 1945; Kates 1963; Burton et al. 1965).

Another important approach in the rationalist paradigm is psychometric research (Birkholtz et al. 2014) (Fig. 1). This theory has been introduced by Fischhoff et al. (1978) and Slovic (1987) and interprets risk as a cognitive construct that can be described psychometrically to reveal quantitative levels of evaluation (De Marchi 2007). The psychometric approach was initially developed by psychologists as a way of quantifying the individual perception of risk. It assumes that people interpret the world in terms of cause-and-effect patterns, and the existence of cognitive patterns allows modeling (by statistical methods) of a psychological phenomenon (Armaş Avram 2008; Kellens et al. 2013). In psychometric studies, questionnaire surveys are the most often used source of data acquisition and help researchers search for cognitive variables that affect the perception of risk.

In the initial phase of psychometric research, researchers have focused on describing the qualitative characteristics of various types of risks (from environmental, through technological, to everyday risks such as communication), which were then replicated in different countries (Fischhoff et al. 1978; Slovic et al. 1980; Vlek Stallen 1981; Otway von Winterfeldt 1982; Englander et al. 1986; Teigen et al. 1988; Keown 1989; Goszczyńska et al. 1991; KarpowiczLazreg Mullet 1993; Poumadere et al. 1995; Kleinhesselink Rosa 1991, 1994). Later, the qualitative features of risk characterization were eliminated in favor of studying the relationship between risk perception and socio-demographic predictors such as gender, age, education, income, or social status (e.g., Flynn et al. 1994; Gustafson 1998; Siegrist Gutscher 2008; Lindell Hwang 2008; Oasim et al. 2015). Additionally, the group of examined explanatory variables has been gradually extended by others, for example, in the field of exposure to risk or disaster experiences (Kellens et al. 2011; Bera Daněk 2018). Subsequently, as part of psychometric research, attention has been focused on the study of adaptive behavior toward risk-to search for predictors of desired attitudes (Miceli et al. 2008; Grothmann Reusswig 2006; Botzen et al. 2009a; b).

Thus, the constructivist paradigm largely rejects the idea that the assessment of threats is an objective phenomenon, external to the social system. Under this approach, threats are perceived as socially constructed and closely related to the dynamics of changes in the social system, for example, values, beliefs, culture, institutions, and organizations. (Drake 1992; Oliver-Smith 1996; Tierney 1999; Weichselgartner 2001; Johnson et al. 2004). The constructivist paradigm promotes the concept of risk as a contextual phenomenon (Birkholtz et al. 2014); it assumes that an individual's judgments and decision-making processes are shaped and limited by social environments (Kates 1963; Drake 1992; Tierney 1999; Slovic 2000). The constructivist paradigm therefore recommends a more comprehensive analysis of how the socio-cultural context shapes a broader understanding of risk; it draws attention to the mechanisms by which risk perception can be disseminated and legitimized at a broader social level (Tierney 1999). The constructivist paradigm provides insights into factors that drive, transform, and moderate the dynamics between risk perception and management, for example, organizational, institutional, and social factors. For example, Tierney (1999) provides a penetrating picture of how institutions dictate to the public the understanding of risk and how social inequalities combine with exposure to risk. Other works have also used the constructivist paradigm for risk perception, for example, Hilgartner (1992), Short and Clarke (1992), Clarke and Short (1993).

One important theoretical current associated with constructivist thinking is cultural theory, which assumes that the perception and acceptance of risk are rooted in social and cultural norms (Shaw et al. 2004) (Fig. 1). Proponents of cultural theory suggest that it is possible to determine the probable perception of risk derived from cultural affiliation and social understanding. In this theory, attention is paid to how the structures of a social organization convey and strengthen the perception of risk by an individual (Douglas Wildavsky 1982). The concept of risk in society according to the cultural theory is considered in a broader perspective, embracing moral values and considerations, as well as political, social, and ideological issues (see Douglas Wildavsky 1982; Rayner Cantor 1987; Thompson et al. 1990; Wildavsky Dake 1990; Dake 1991; Douglas 1992). For example, Douglas and Wildavsky (1982) link four "worldview(s)" 
(individualistic, egalitarian, hierarchical, and fatalistic) with some attitudes toward risk. These "worldview(s)" proposed by Douglas (1978) are the expression of the application of cultural theory in risk perception studies because they reflect the combination of "cultural prejudices" (common values and beliefs) and "social relations" (models of interpersonal relations).

The line of research conducted both in the rationalist and constructivist paradigms is "heuristics". Heuristics, that is, simple and effective principles, are often used to simplify complex problems and make decisions without using all cognitive abilities (Kellens et al. 2013). In studies of flood risk perception, the heuristic of accessibility and the heuristic of affect have been considered the most (Fig. 1). The first one defined by cognitive psychologists refers to what people remember and not what actually occurred; this is a cognitive pattern for information processing, not a material world's imprint on the mind (Lichtenstein et al. 1978). It is posited that people in conditions of uncertainty are guided by certain mental models that reflect the human thought process and refer to an individual's assessment of the situation (Birkholtz et al. 2014). In risk assessment studies, the role of heuristic diagrams in decision-making has been demonstrated, namely, threats that are more dramatic and spectacular can be more easily remembered, and their higher cognitive "availability" can explain the tendency among respondents to overestimate the risk of such threats (Lichtenstein et al. 1978). Papers in cognitive psychology have indicated that cognitive models and mental mechanisms of risk assessment are constantly moderated (modified, strengthened, or weakened) by media reports and influenced by friends, family, and various communication processes (Morgan et al. 2001). Research on risk perception (e.g., environmental, technological, road, and aviation hazards) has demonstrated the media's influence on the ease of recalling threats, resulting in an overstated risk assessment (Johnson Tversky 1983). Additionally, Boholm (1998) emphasized that if the heuristic of accessibility is to be taken seriously as a theoretical framework for understanding risk perception, attention should be paid to how threats are represented socially, for example, in the media.

This perspective has more often been reflected in constructivist than rationalistic research. The heuristic of affect, thus says that mental representations are "marked" by weak negative or positive feelings. Finucane et al. (2000) showed that the perception of risk is an "affect marker," namely, risk assessment often occurs under the influence of emotions. Siegrist and Gutscher (2008), Miceli et al. (2008)' and Terpstra (2011) have also pointed out the importance of affect in perceiving and communicating the risk of flooding.

\section{Classifications Of Flood Risk Perception Factors In The Literature}

Many classifications of factors have been presented in the literature according to their nature (Table 1). Tobin and Montz (1997) distinguish situational and cognitive factors, and Wachinger et al. (2013) identify informational, personal, and contextual agents. Contextual factors have also been observed in Boholm (1998) and Brikholtz et al. (2014). O'Neill et al. (2016) focus on cognitive (behavioral), socioeconomic, and geographic factors. The most recent classification of flood risk perception agents is in Lechowska (2018), in which six groups of factors (cognitive, behavioral, socioeconomic, demographic, geographic [physics], and informational and contextual) were identified. The featured classifications are inconsistent; they are developed at different levels of detail and present different perspectives on the interpretation of the nature of flood risk perception factors. Additionally, they are divided based on diverse criteria for the division. However, none of them considers the application of rationalist or constructivist paradigm. Therefore, it seems worthwhile to categorize the factors used in the research, based on approaches presented in the introduction of this paper, which was done in Sect. 4.3. 


\begin{tabular}{|c|c|c|c|c|}
\hline Paper & \multicolumn{4}{|l|}{ Factors } \\
\hline \multirow{11}{*}{$\begin{array}{l}\text { Tobin, } \\
\text { Montz } \\
\text { (1997) }\end{array}$} & \multicolumn{3}{|c|}{ Situational factors: } & Cognitive factors: \\
\hline & \multirow{2}{*}{\multicolumn{3}{|c|}{$\begin{array}{l}\text { - the physical location reflecting proximity to a hazard (the probability of } \\
\text { the occurrence of flood); } \\
\text { - the nature of the flood (since a violent mountain flood is perceived } \\
\text { differently to a lowland flood that is long-term in nature and can be } \\
\text { predicted beforehand); }\end{array}$}} & $\begin{array}{l}\text { the personal and psychological elements of an individual and } \\
\text { comprise emotional and behavioural attributes which }\end{array}$ \\
\hline & & & & tendencies to act in a specific way due to the flood \\
\hline & \multicolumn{3}{|c|}{ - the extent of the effects; } & \\
\hline & \multicolumn{3}{|l|}{ - the experience } & \\
\hline & \multicolumn{3}{|c|}{ - the level of hazard awareness and the degree of its uncertainty; } & \\
\hline & \multicolumn{3}{|c|}{$\begin{array}{l}\text { - socio-economic and demographic factors of the population (gender, } \\
\text { age, education, income, number of children); }\end{array}$} & \\
\hline & \multicolumn{3}{|c|}{$\begin{array}{l}\text { - the residence characteristics (owning a house, type of a building, } \\
\text { presence of a ground floor, cellar); }\end{array}$} & \\
\hline & \multicolumn{3}{|c|}{ •the cultural-historical context; } & \\
\hline & \multicolumn{3}{|c|}{ •voluntary/involuntary nature; } & \\
\hline & \multicolumn{3}{|c|}{$\begin{array}{l}\text { - the group of people influenced by the flood (individuals can perceive a } \\
\text { risk differently, depending on whether they are directly influenced } \\
\text { themselves, their families are influenced or it regards people they are not } \\
\text { connected to emotionally). }\end{array}$} & \\
\hline \multirow{5}{*}{$\begin{array}{l}\text { Boholm } \\
\text { (1998) }\end{array}$} & \multicolumn{3}{|c|}{ Contextual factors: } & \\
\hline & \multicolumn{3}{|l|}{ • gender } & \\
\hline & \multicolumn{3}{|c|}{ • social marginalisation } & \\
\hline & \multicolumn{3}{|l|}{ - education } & \\
\hline & \multicolumn{3}{|l|}{ - occupation } & \\
\hline \multirow{12}{*}{$\begin{array}{l}\text { Wachinger } \\
\text { et al. } \\
\text { (2013) }\end{array}$} & \multirow{12}{*}{$\begin{array}{l}\text { Risk factors: } \\
\text { - scientific } \\
\text { characteristics } \\
\text { of a risk } \\
\text { - perceived } \\
\text { probability of } \\
\text { the occurrence }\end{array}$} & \multirow{12}{*}{$\begin{array}{l}\text { Informational } \\
\text { factors: } \\
\text { - the source } \\
\text { of } \\
\text { information } \\
\text { - level of } \\
\text { information }\end{array}$} & Personal factors: & Contextual factors: \\
\hline & & & • gender & · economic factors, \\
\hline & & & $\cdot$ age & •vulnerability indices, \\
\hline & & & - education & • home ownership, \\
\hline & & & - occupation & - family status, country, \\
\hline & & & - personal knowledge & - area of living, \\
\hline & & & - personal disaster experience & - closeness to the waterfront, \\
\hline & & & - trust in authorities & · size of community, \\
\hline & & & - trust in experts & - age of the youngest child \\
\hline & & & $\begin{array}{l}\text { - confidence in different risk } \\
\text { reduction measures }\end{array}$ & \\
\hline & & & • world views & \\
\hline & & & - religiousness & \\
\hline Brikholtz et & \multicolumn{3}{|c|}{ Contextual factors: } & \\
\hline & \multicolumn{3}{|c|}{ • structural constraints } & \\
\hline & \multicolumn{3}{|c|}{ - the political/economic forces } & \\
\hline \multirow{7}{*}{$\begin{array}{l}\text { O'Neill et } \\
\text { al. }(2016)\end{array}$} & \multicolumn{2}{|c|}{ Cognitive (behavioural) factors: } & Socio-economic factors: & Geographical factors: \\
\hline & \multicolumn{2}{|c|}{ - direct experience of flood } & $\cdot$ age & - distance or proximity to a hazard. \\
\hline & - flood losses & & - gender & \\
\hline & $\begin{array}{l}\text { - emotional and } \\
\text { reactions }\end{array}$ & fective & - civil status & \\
\hline & . fear & & - education & \\
\hline & & & • income & \\
\hline & vority & & - holding of a building & \\
\hline
\end{tabular}




\begin{tabular}{|c|c|c|c|c|c|c|}
\hline Paper & Factors & & & & & \\
\hline $\begin{array}{l}\text { Lechowska } \\
\text { (2018) }\end{array}$ & $\begin{array}{l}\text { Cognitive } \\
\text { factors: } \\
\text { - worry, } \\
\text { - direct } \\
\text { experience }\end{array}$ & $\begin{array}{l}\text { Behavioural } \\
\text { factors: } \\
\text { preparedness }\end{array}$ & 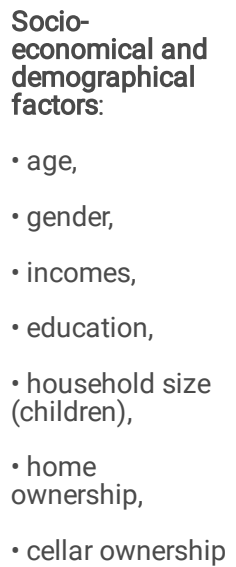 & $\begin{array}{l}\text { Geographical } \\
\text { (physical) } \\
\text { factors: } \\
\text { - location } \\
\text { (hazard), } \\
\text { • hazard } \\
\text { proximity, } \\
\text { - type of } \\
\text { building (living } \\
\text { on ground } \\
\text { floor), } \\
\text { - length of } \\
\text { residence }\end{array}$ & $\begin{array}{l}\text { Informational } \\
\text { factors: } \\
\text { - awareness } \\
\text { (knowledge), } \\
\text { - indirect experience } \\
\text { (media) }\end{array}$ & $\begin{array}{l}\text { Contextual factors: } \\
\text { - culture, } \\
\text { - religion, } \\
\text { - history, } \\
\text { - political system (government policy), } \\
\text { - social bonds (type of social capital), } \\
\text { - trust in government and public } \\
\text { protection measures }\end{array}$ \\
\hline
\end{tabular}

\section{Research Design}

\subsection{Methods}

To achieve the goal set in the introduction, a research procedure was conducted comprising stages shown in Fig. 2.

The empirical works devoted to flood risk assessment research published in 1998-2018 to capture contemporary trends in research in this area were selected in the following manner: (a) the empirical works were selected from Google Scholar, the Web of Science/Knowledge, and Scopus databases by using a keyword combination, namely, flood, factors, risk perception, flood risk, preparedness, worry, awareness, threat, risk underestimation, and denial; (b) in the selected articles, the following sections were reviewed in the following order-abstract, introduction, discussion, and conclusion-(c) which allowed for the development of an initial list of factors that may affect the perception of flood risk and its basic characteristics; (d) if the aforementioned parts of the article focused on the aforementioned subject matter, this article was subject to a deeper review (i.e., entire text); (e) further selection of research was made using the "snowballing" strategy (the reference list was consulted for other papers). As a result, the review includes 49 empirical works that focus on determining the level of perception of flood risk and identifying its possible factors. The catalog of variables adopted in the analyzed studies results either from the purpose of the research or an earlier literature review conducted by the authors of the analyzed works.

In the second stage, a categorization was conducted of the factors examined according to their character and the concept used, and flood risk factors were assigned to prearranged categories based on how they were applied in particular research approaches (rationalist and constructivist).

To determine the dynamics of changes in the substantive scope of research on flood risk perception factors, the changes in dynamics of occurrence frequency of the given groups of flood risk perception factors were analyzed in the third stage. For this purpose, a frequency factor was used, which expresses the percentage share of consideration of a given factor in the total number of considerations of all factors in research articles in the period studied. This allowed us to answer the question of which paradigm dominates the research of flood risk perception?

In the next stage, the summary of results based on the adopted research approach was prepared to assess whether the test results of a given approach were unambiguous or mutually exclusive. This allowed the question to be answered in the first place of what is the relationship between rationalistic and constructivist factors (e.g. stimulation, weakening, strengthening, etc.) and ultimately answer the question of what is the relationship between the results of research conducted in a rationalistic and constructivist approach (e.g. complementary, supportive, antagonistic, etc.)??

The above-mentioned stages made it possible to achieve the main goal of the study, i.e. to answer the research questions posed in the introduction. At the end recommendations were formulated on what should be the direction of flood risk perception studies to improve flood risk management?

\subsection{Selected empirical studies}

As a result of the first stage of the review, 49 empirical studies on the factors of flood risk perception were selected (Table 2). The analyzed set of research papers was strongly diversified in the applied research methods, often resulting from the research goal. Studies (mostly questionnaires or interviews) had various characteristics: the use of online surveys (Bradford et al. 2012), telephone surveys (Grothmann Reusswig 2006; Becker et al. 2013; Działek et al. 2013a, b), local schools (Działek et al. 2013b), mailboxes (Werritty et al. 2007; Kellens et al. 2011; Bradford et al. 2012), personal communication (Pagneux et al. 2011), "door-to-door" questionnaire interviews (Duží et al. 2015; Stojanov et al. 2015), semi-structural interviews (Fitton et al. 2015; Bustillos Ardaya et al. 2017), in-depth interviews (Działek et al. 2013b), and focus groups (Werritty et al. 2007; Działek et al. 2013b). Sampling methods also varied, namely, accidental (Pagneux et al. 2011), random (Armaş Avram 2008), and snowball (Fitton et al. 2015). 
Table 2

Factors taken into account in studies of flood risk perception.

\begin{tabular}{|c|c|c|c|c|c|c|c|c|c|c|}
\hline \multirow[t]{2}{*}{ No } & \multirow[t]{2}{*}{ Paper } & \multicolumn{8}{|c|}{ Rationalist paradigm } & \multirow{2}{*}{$\begin{array}{l}\text { Constn } \\
\begin{array}{l}\text { Indirect } \\
\text { experie }\end{array}\end{array}$} \\
\hline & & $\begin{array}{l}\text { Individual's } \\
\text { physical } \\
\text { location }\end{array}$ & $\begin{array}{l}\text { Flood } \\
\text { characteristics }\end{array}$ & $\begin{array}{l}\text { Residence } \\
\text { characteristics }\end{array}$ & $\begin{array}{l}\text { Size of } \\
\text { consequences }\end{array}$ & $\begin{array}{l}\text { Range } \\
\text { of } \\
\text { impact }\end{array}$ & $\begin{array}{l}\text { Direct } \\
\text { experience }\end{array}$ & $\begin{array}{l}\text { Socio- } \\
\text { economic } \\
\text { and } \\
\text { demographic } \\
\text { profiles }\end{array}$ & $\begin{array}{l}\text { Information } \\
\text { (knowledge) }\end{array}$ & \\
\hline 1 & $\begin{array}{l}\text { Sjöberg } \\
\text { (1998) }\end{array}$ & & & & & $x$ & & $x$ & & \\
\hline 2 & King (2000) & & & & & & & & $x$ & \\
\hline 3 & $\begin{array}{l}\text { Schmuck } \\
\text { (2000) }\end{array}$ & & & & & & & & & \\
\hline 4 & $\begin{array}{l}\text { Barnett } \\
\text { Breakwell } \\
(2001)\end{array}$ & & & & & & $x$ & & & \\
\hline 5 & $\begin{array}{l}\text { Cutter et al. } \\
(2003)\end{array}$ & & & & & & & $x$ & & $x$ \\
\hline 6 & $\begin{array}{l}\text { Takao et al. } \\
(2004)\end{array}$ & & & $x$ & $x$ & & & & & \\
\hline 7 & $\begin{array}{l}\text { Baan Klijn } \\
(2004)\end{array}$ & & & & & & $x$ & $x$ & & \\
\hline 8 & $\begin{array}{l}\text { Kreibich et al. } \\
(2005)\end{array}$ & & & & & & $x$ & & & \\
\hline 9 & $\begin{array}{l}\text { Grothmann } \\
\text { Reusswig } \\
\text { (2006) }\end{array}$ & & & $x$ & $x$ & & $x$ & $x$ & & \\
\hline 10 & $\begin{array}{l}\text { Thieken et al. } \\
(2007)\end{array}$ & & & & & & $\mathrm{x}$ & & $x$ & \\
\hline 11 & $\begin{array}{l}\text { Knocke and } \\
\text { Kolivras } \\
(2007)\end{array}$ & & & & & & & $x$ & & \\
\hline 12 & $\begin{array}{l}\text { Werritty et al. } \\
(2007)\end{array}$ & $x$ & $\mathrm{x}$ & $x$ & $\mathrm{x}$ & $\mathrm{x}$ & $x$ & $x$ & & \\
\hline 13 & $\begin{array}{l}\text { Raaijmakers } \\
\text { et al. (2008) }\end{array}$ & & & & $\mathrm{x}$ & & & & $x$ & \\
\hline 14 & $\begin{array}{l}\text { Siegrist } \\
\text { Gutscher } \\
\text { (2008) }\end{array}$ & & & & $x$ & & $x$ & $x$ & $x$ & \\
\hline 15 & $\begin{array}{l}\text { Lindell } \\
\text { Hwang } \\
(2008)\end{array}$ & & & $x$ & & & $x$ & $x$ & $x$ & \\
\hline 16 & $\begin{array}{l}\text { Miceli et al. } \\
(2008)\end{array}$ & $\mathrm{x}$ & & & $x$ & $x$ & $x$ & $x$ & $x$ & \\
\hline 17 & $\begin{array}{l}\text { Ho et al. } \\
\text { (2008) }\end{array}$ & & $\mathrm{x}$ & & $x$ & & & & & \\
\hline 18 & $\begin{array}{l}\text { Burningham } \\
\text { et al. (2008) }\end{array}$ & & & & & & $x$ & $x$ & & \\
\hline 19 & $\begin{array}{l}\text { Terpstra } \\
\text { Gutteling } \\
\text { (2008) }\end{array}$ & & & & & & & & & \\
\hline 20 & $\begin{array}{l}\text { Armas Avram } \\
\text { (2008) }\end{array}$ & & & $x$ & & & $x$ & $x$ & & \\
\hline 21 & $\begin{array}{l}\text { Biernacki et } \\
\text { al. (2009) }\end{array}$ & & & $x$ & $x$ & & $x$ & & $x$ & $x$ \\
\hline 22 & $\begin{array}{l}\text { Botzen et al. } \\
\text { (2009a) }\end{array}$ & $x$ & & & & & $x$ & $x$ & $x$ & \\
\hline 23 & $\begin{array}{l}\text { Botzen et al. } \\
(2009 b)\end{array}$ & $x$ & & & & & & & $x$ & \\
\hline 24 & $\begin{array}{l}\text { Zaalberg et } \\
\text { al. (2009) }\end{array}$ & & & & & & $x$ & $x$ & & \\
\hline
\end{tabular}




\begin{tabular}{|c|c|c|c|c|c|c|c|c|c|c|}
\hline \multirow[t]{2}{*}{ No } & \multirow[t]{2}{*}{ Paper } & \multicolumn{8}{|c|}{ Rationalist paradigm } & \multirow{2}{*}{$\begin{array}{l}\text { Constn } \\
\text { Indirect } \\
\text { experie }\end{array}$} \\
\hline & & $\begin{array}{l}\text { Individual's } \\
\text { physical } \\
\text { location }\end{array}$ & $\begin{array}{l}\text { Flood } \\
\text { characteristics }\end{array}$ & $\begin{array}{l}\text { Residence } \\
\text { characteristics }\end{array}$ & $\begin{array}{l}\text { Size of } \\
\text { consequences }\end{array}$ & $\begin{array}{l}\text { Range } \\
\text { of } \\
\text { impact }\end{array}$ & $\begin{array}{l}\text { Direct } \\
\text { experience }\end{array}$ & $\begin{array}{l}\text { Socio- } \\
\text { economic } \\
\text { and } \\
\text { demographic } \\
\text { profiles }\end{array}$ & $\begin{array}{l}\text { Information } \\
\text { (knowledge) }\end{array}$ & \\
\hline 25 & $\begin{array}{l}\text { Terpstra et al. } \\
(2009)\end{array}$ & & & & & & $\mathrm{x}$ & & & $x$ \\
\hline 26 & $\begin{array}{l}\text { Terpstra } \\
(2009)\end{array}$ & & & & & & $x$ & $\mathrm{x}$ & & \\
\hline 27 & Hung (2009) & & & $x$ & & & & $x$ & & \\
\hline 28 & $\begin{array}{l}\text { Heitz et al. } \\
(2009)\end{array}$ & & & & & & & & $\mathrm{x}$ & \\
\hline 29 & $\begin{array}{l}\text { Zhang et al. } \\
(2010)\end{array}$ & $x$ & & & & & & & & \\
\hline 30 & $\begin{array}{l}\text { Kellens et al. } \\
(2011)\end{array}$ & $\mathrm{x}$ & & $\mathrm{x}$ & & & $\mathrm{x}$ & $\mathrm{x}$ & & \\
\hline 31 & $\begin{array}{l}\text { Kreibich et al. } \\
(2011)\end{array}$ & & & & & & $x$ & & & \\
\hline 32 & $\begin{array}{l}\text { Pagneux et al. } \\
(2011)\end{array}$ & & & & & & $x$ & & & \\
\hline 33 & $\begin{array}{l}\text { Scheuer et al. } \\
\text { (2011) }\end{array}$ & & & & & & & $\mathrm{x}$ & & \\
\hline 34 & $\begin{array}{l}\text { Terpstra } \\
(2011)\end{array}$ & & & & & & $x$ & & & \\
\hline 35 & $\begin{array}{l}\text { Botzen van } \\
\text { den Bergh } \\
(2012)\end{array}$ & & & & & & $x$ & $\mathrm{x}$ & $\mathrm{x}$ & \\
\hline 36 & $\begin{array}{l}\text { Bradford et al. } \\
\text { (2012) }\end{array}$ & & & & & & $x$ & $\mathrm{x}$ & & \\
\hline 37 & $\begin{array}{l}\text { Ludy Kondolf } \\
(2012)\end{array}$ & $x$ & & & & & $x$ & $x$ & & \\
\hline 38 & $\begin{array}{l}\text { Bichard } \\
\text { Kaźmierczak } \\
(2012)\end{array}$ & & & & & & & & $x$ & \\
\hline 39 & $\begin{array}{l}\text { Działek et al. } \\
\text { (2013a) }\end{array}$ & & & $\mathrm{x}$ & & & & & $x$ & $x$ \\
\hline 40 & $\begin{array}{l}\text { Działek et al. } \\
(2013 b)\end{array}$ & & & $x$ & & & & & $x$ & $x$ \\
\hline 41 & $\begin{array}{l}\text { Poussin et al. } \\
\text { (2014) }\end{array}$ & & & & & & & $x$ & & \\
\hline 42 & $\begin{array}{l}\text { Duží et al. } \\
\text { (2015) }\end{array}$ & $x$ & & & & & $x$ & $\mathrm{x}$ & $\mathrm{x}$ & \\
\hline 43 & $\begin{array}{l}\text { Oasim et al. } \\
(2015)\end{array}$ & $x$ & & $\mathrm{x}$ & & & $x$ & $x$ & & \\
\hline 44 & $\begin{array}{l}\text { Stojanow et } \\
\text { al. (2015) }\end{array}$ & & & $x$ & $\mathrm{x}$ & & $x$ & $\mathrm{x}$ & & \\
\hline 45 & $\begin{array}{l}\text { Armas et al. } \\
(2015)\end{array}$ & & & & & & $x$ & & $x$ & \\
\hline 46 & $\begin{array}{l}\text { O'Neill et al. } \\
(2016)\end{array}$ & $x$ & & & & & & & & \\
\hline 47 & $\begin{array}{l}\text { Bustillos } \\
\text { Ardaya et al. } \\
\text { (2017) }\end{array}$ & $\mathrm{x}$ & & & & & $\mathrm{x}$ & $\mathrm{x}$ & $\mathrm{x}$ & $\mathrm{x}$ \\
\hline 48 & $\begin{array}{l}\text { Thistlethwaite } \\
\text { et al. (2018) }\end{array}$ & & & $x$ & & $\mathrm{x}$ & $x$ & $x$ & & \\
\hline \multirow[t]{2}{*}{49} & $\begin{array}{l}\text { Bera Danek } \\
(2018)\end{array}$ & $x$ & & & & $\mathrm{x}$ & $x$ & $x$ & & \\
\hline & Summary & 11 & 1 & 12 & 8 & 4 & 28 & 25 & 17 & 6 \\
\hline
\end{tabular}


To determine the impact of individual factors on the perception of flood risk, various statistical methods were used in the empirical studies under analysis, for example, regression analysis (Grothmann Reusswig 2006; Siegrist Gutscher 2008; Miceli et al. 2008; Lindell Hwang 2008; Kellens et al. 2011; Duží et al. 2015; Stojanov et al. 2015), one-way ANOVA analysis of variance (Armaş Avram 2008; Pagneux et al. 2011; Bradford et al. 2012), correlation analysis (Takao et al. 2004; Kreibich et al. 2005; Grothmann Reusswig 2006; Thieken et al. 2006, 2007; Knocke Kolivras 2007; Miceli et al. 2008; Lindell Hwang 2008; Kellens et al. 2011), Student's t test for independent trials (Bradford et al. 2012), and the chi-square test (Werritty et al. 2007; Bradford et al. 2012).

The studies were conducted in various circumstances, for example, at different times since the last flood or investment in the field of flood protection. The analyzed works presented research covering various countries (in Europe, Asia, and North America) with different religions, cultures, political and economic systems, and geographical determinants.

\subsection{Categorization of flood risk perception factors based on the applied research approach}

The flood risk factor perception was classified as rationalist or constructivist based on the method, in which the factor was included in the study, what role it played, and how it was interpreted by the researchers. Thus, the researcher's approach to the research determined the class that the factor was assigned to. The same factor could be treated as a cognitive variable, a predictor in modeling cognitive patterns, as an element of a cause-effect scheme of conduct in a "rational" decision process or as a socially constructed element in a context's meaning. However, the classes are not dichotomous, and some factors can be assigned to many categories (e.g., gender can be used as rationalist or be socially defined/constructed). For the purpose of this work, mixed factors were also assigned to one of the categories by considering the researcher's perception of the factor.

As a result, the following classes of factors were included in the rationalist paradigm: individual's physical location, flood characteristics, residence characteristics, size of consequences, range of impact, direct experience, socioeconomic and demographic profiles, and information (knowledge). Accordingly, to constructivist paradigm agents such as indirect experience, the cultural-historical, religious, and political contexts were assigned (Fig. 3).

\section{Results}

\subsection{Evolution of substantive scope of research on flood risk perception factors}

From 1998 to 2018, the greatest interest in the study of factors shaping the perception of flood risk was in 2008 and 2009 . These works are mostly from northern Europe (the Netherlands, Denmark, England) and Taiwan and to a lesser extent from Western Europe (France, Switzerland, Northern Italy). In 2011 and 2015, we observe more interest from researchers from Germany and Belgium and then from the Czech Republic and Romania. At present, there is a decline in the interest of researchers in flood risk perception (Fig. 4).

The empirical studies analyzed discuss factors that may influence the perception of flood risk (Table 2). These studies are mostly from the rationalist perspective because they concern groups of variables such as an individual's physical location, flood characteristics, size of consequences, range of impact, direct experience, socioeconomic and demographic profiles, and information (knowledge). The frequency factor for considering the aforementioned factors in the analyzed papers is $86.5 \%$ (these factors were considered 115 times of the 133 accounts). Other factors, such as the indirect experiences, culturalhistorical contexts, and religious and political contexts expressed the constructivist paradigm, are to a lesser extent considered in studies of flood risk perception (the frequency factor for their inclusion is $13.5 \%$, i.e., 18 of 133; Fig. 5).

The psychometric approach prevails in the collected research works in the rationalist paradigm. The authors of these papers are attempting to statistically describe the phenomenon of social research. These papers present a quantitative analysis of individual risk perception, assuming the existence of cognitive patterns that allow the studied phenomena to be modeled (Fischhoff et al. 1978; De Marchi 2007; Kellens et al. 2013). Therefore, in the aforementioned papers, these factors appear mainly as independent variables included in the modeling of the perception of flood risk.

In studies of the perception of flood risk conducted in the rationalist approach, the impact of direct flood experience on the level of risk perception is considered (30 of 115 inclusions; thus, the frequency factor is $26.1 \%$ ), followed by social, economic, and demographic factors (27 times, i.e., $23.5 \%$; Fig. 4 ). Other factors less frequently considered in the studies of flood risk perception are knowledge level (14.8\%), residence characteristics (11.3\%), and individual's physical location (10.4\%). Other groups of factors, such as the size of consequences, flood characteristics, and the range of impact, are considered to a negligible extent (frequency factor below $10.0 \%$ ).

In the works conducted using the constructivist paradigm, the political context is most often considered (8 of 18 inclusions, i.e., the frequency factor is $44.4 \%$ ), followed by indirect experience ( 6 times, or $33.3 \%$; Fig. 4). Cultural-historical and religious contexts are included to a lesser extent (frequency factor of $16.7 \%$ and $5.6 \%$, respectively).

In analyses of the development of researchers' interest in particular groups of factors that may influence the perception of flood risk, the focus is initially on rationalistic factors. From 1998 to 2001, the impact of socioeconomic and demographic profiles and the range of impact and information (knowledge) on the level of perception of flood risk are of great interest. From 2002 to 2007, the focus is on direct experience and the related size of consequences, as well as residence characteristics. From 2008 to 2018, researchers focus on factors such as direct experience, socioeconomic and demographic profiles, information (knowledge), and residence characteristics, as well as an individual's physical location (Fig. 6).

Thus, regarding constructivist factors (indirect experience and political, cultural-historical, and religious contexts), they began to be considered in empirical works on the perception of flood risk in 2009, later than the rationalist factors. From 1998 to 2003, research on the perception of flood risk primarily focuses 
on the religious context and interpersonal communication networks (shaping intermediate experience). From 2004 to 2012 , the primary focus is political context, and from 2013 to 2018, the cultural and historical contexts (Fig. 6).

\subsection{Impact of individual factors on the flood risk perception}

The papers under discussion concern the analysis of the impact of individual factors on the perception of flood risk and the analysis of the interrelationship between the three characteristics of flood risk perception: preparedness, worry, and awareness (mentioned by Raaijmakers et al. 2008). Therefore, the next part of this section presents the results of research on the impact of each factor on the three aspects of the perception of flood risk and in general on the level of perceived flood risk.

\section{Rationalist approach}

The most attention is paid to factors that affect the perception of risk and its three basic characteristics, followed by those factors that have no unequivocal influence on the studied phenomenon, and then the group of problematic factors (affecting perception).

Empirical research demonstrates that the transfer of information and the education of the public increase awareness (King 2000; Raaijmakers et al. 2008), similar to the experience of flooding (Lindell Hwang 2008) and the very fact of the flood (Biernacki et al. 2009). Studies have also shown that people with a lower education are more worried about floods than those with a higher education are (Sjöberg 1998; Bradford et al. 2012). Bradford et al. (2012) assume that there is a relationship between education and income level and conclude that individuals with higher incomes are less worried about the consequences of flooding than those with lower incomes are (Fig. 7).

A relationship is also demonstrated between gender and having children and preparedness: men and households with children are more likely to take preventive measures (Stojanov et al. 2015; Fitton et al. 2015). In addition, Grothmann and Reusswig (2006), Harries and Penning-Rowsell (2011)' and Thistlethwaite et al. (2018) have demonstrated a positive impact of owning a home on taking mitigation measures. For preventive behaviors, the type of building is also important. Applying security measures is much lower for multi-family buildings than for single-family buildings (Działek et al. 2013a, b; Biernacki et al. 2009).

Empirical studies demonstrate the impact of knowledge on the perception of risk. People with little knowledge have a lower risk perception (Messner Meyer 2006; Raaijmakers et al. 2008; Botzen et al. 2009a; Biernacki et al. 2009; Działek et al. 2013a; Wachinger et al. 2013). Many studies have emphasized the significance of an individual's experience in shaping the perception of flood risk (Barnett Breakwell 2001; Slovic et al. 2004; Kreibich et al. 2005; Grothmann Reusswig 2006; Armaş Avram 2008; Siegrist Gutscher 2008; Zaalberg et al. 2009; Botzen et al. 2009a; Kellens et al. 2011; Duží et al. 2015; Bustillos Ardaya et al. 2017). People who have been directly affected by floods are characterized by a higher level of perception of flood risk (Kellens et al. 2011; Oasim et al. 2015; Thistlethwaite et al. 2018; Fig. 7).

Another factor that influences the perception of flood risk is gender. Kellens et al. (2011), Bustillos Ardaya et al. (2017), and Lindell and Hwang (2008) have unequivocally indicated that women usually perceive a higher level of flood risk (Fig. 7).

In the research in the rationalist trend, researchers have demonstrated the influence of particular factors on the perception of flood risk but often excluded their impact (Fig. 7).

Socioeconomic features such as income, age, gender, and education do not affect awareness. Many studies have also demonstrated very little or no effect of education on precaution (Sjöberg 1998; Grothmann Reusswig 2006; Lindell Hwang 2008; Zaalberg et al. 2009; Botzen et al. 2009a). In addition, the distance from the threat (river) seems to have little effect on mitigating behaviors (Lindell Hwang 2008; Miceli et al. 2008; Botzen et al. 2009a). It has also been shown that neither income (Botzen et al. 2009a; Oasim et al. 2015) nor household size (Takao et al. 2004; Zaalberg et al. 2009; Oasim et al. 2015) have a significant impact on the perception of flood risk. Residence characteristics such as having a basement or living on the ground floor do not affect the level of perception of flood risk, as Kellens et al. (2011; Fig. 7) demonstrate.

A group of factors whose impact on the perception of flood risk is ambiguous is problematic. Bradford et al. (2012) do not show a strong relationship between anxiety and gender, whereas according to Sjöberg (1998) and Poorting et al. (2011) women more often show anxiety in response to perceived threats. There is also no match between the results of research on the impact of experience and knowledge (information) on the level of preparedness. Positive dependence between the experience of flood and the degree of involvement in the preparation of individual mitigation measures has been demonstrated by Takao et al. (2004), Slovic et al. (2004), Grothmann and Reusswig (2006), Siegrist and Gutscher (2006), Lamond et al. (2009), Biernacki et al. (2009), Terpstra (2011), Kreibich et al. (2011), Stojanow et al. (2015), and Thistlethwaite et al. (2018), and the correlation and regression values obtained have often been low or average (Grothmann Reusswig 2006; Thieken et al. 2007; Siegrist Gutscher 2008; Lindell Hwang 2008; Miceli et al. 2008). By contrast, Takao et al. (2004) and Thieken et al. (2007) and Duží et al. (2015) do not show such dependence. The level of knowledge of floods, according to Thieken et al. (2007), Miceli et al. (2008), weakly correlate positively with preventive actions, and Botzen et al. (2009a) show that the increase in knowledge of a threat reduces the willingness of the population to invest in protective measures; however, Siegrist and Gutscher (2008) show no such dependence (Fig. 8).

The results of the analyzed studies also ambiguously specify the relationship between the location in flood hazard zones and undertaking preventive actions. According to Duží et al. (2015), with an increase in hazard level, risk mitigation measures are more often used. Kunreuther (1996), by contrast, notes that people living in the most vulnerable areas rarely voluntarily take precautionary measures, increasing their vulnerability to disasters (Fig. 8).

Age and income are the factors that have an ambiguous effect on readiness in the analyzed papers. According to some researchers, the age of inhabitants of flood zones has little or no significance in undertaking individual protective actions (Knocke Kolivras 2007; Lindell Hwang 2008; Zaalberg et al. 2009; Botzen et al. 2009a), while Działek et al. (2013a), Grothmann and Reusswig (2006) show that older residents of these areas more often decide to use preventive

Page 10/23 
measures. The significance of income for floodplain inhabitants taking preventive measures is low, according Lindell and Hwang (2008), Botzen et al. (2009a), and Zaalberg et al. (2009), but according to Grothmann and Reusswig (2006), Stojanow et al. (2015), and Thistlethwaite et al. (2018) more affluent residents are more willing to invest in flood mitigation measures (Fig. 8).

Kellens et al. (2011) show that older people usually assess the risk of flooding as higher than younger people, but according to Oasim et al. (2015) and Armas et al. (2015), age has no significant impact on the perception of flood risk. The level of education, according to Kellens et al. (2011) and Armas et al. (2015), is not decisive in risk perception, by Oasim et al. (2015) and Botzen et al. (2009a) prove that the level of education increases the perception of flood risk (Fig. 8).

The analyzed literature suggests that real estate ownership is associated with a higher level of perception of flood risk than apartment rental (Grothmann Reusswig 2006; Burningham et al. 2008; Oasim et al. 2015), and Kellens et al. (2011) shows no such a relationship (Fig. 8).

This discrepancy in the results also applies to the impact of the proximity of the hazard (river) on the level of perceived risk. According to some studies, the proximity of the source of hazard results in a higher perception of flood risk (Lindell Hwang 2008; Miceli et al. 2008; Zhang et al. 2010; O’Neill et al. 2016), and others posit that the closer the river, the lower the perception of risk, due to the incidental nature of flooding (Oasim et al. 2015; Colten Sumpter 2009). Kellens et al. (2011) obtain no dependencies in this respect (Fig. 8).

The impact of the duration of residence on the perception of flood risk is also unclear. Thistlethwaite et al. (2018) demonstrate a moderate positive relationship, but Bustillos Ardaya et al. (2017) demonstrates a very weak one (Fig. 8).

Therefore, in the empirical works conducted in the rationalist trend, the influence of particular factors on the perception of flood risk in general and its three basic aspects are not always explicit.

\subsubsection{Constructivist approach}

Research conducted using the constructivist approach indicates the great importance of cultural values, religion, political system, history, and types of social bonds in shaping the perception of flood risk (Fig. 9).

In studies that consider the social context, the impact of the communication network in the form of media (Biernacki et al. 2009) and personal interactions with other people (indirect experience) on the assessment of flood risk are considered. Działek et al. (2013a, b) demonstrate that the ability to obtain information and recall the experience depends largely on the type of social structures and social capital. In rural communities and small towns characterized by strong social bonds (bonding social capital), the importance of disseminating information on local hazards between generations by the inhabitants is observed. However, in the case of communities with weak social ties (bridging social capital), such as large cities, indirect experiences of residents are difficult to convey-populations are more mobile and personal interactions between people are limited (Działek et al. 2013a, b; Cutter et al. 2003). According to Terpstra et al. (2009), other people's experiences and reports communicated through social communication (e.g., the effects of floods experienced by friends, relatives, neighbors, and other people) have a smaller impact on risk perception than personal, indirect experience. Media coverage contributes to the perception of risk mainly when the recipient has no flood-related personal, indirect experience (Wachinger et al. 2013), and according to Bustillos Ardaya et al. (2017), information provided at the local level (from neighbors, family, and friends) is more important in shaping risk perception than institutional impacts are.

Because few studies consider the social context in the research on risk perception, we refer to the results of the research with a more general character, namely, those that refer to all hazards (technological, social, natural). Some results have demonstrated (e.g., Johnson Tversky 1983; Short 1984) that media coverage may be biased, which strengthens the dramatism of catastrophic events while weakening the importance of everyday threats. Sjöberg et al. (1996) aptly note that the role of media in risk perception is complex and differs by society. For example, media in communist countries poorly inform residents about hazards and understate risk perception because they are more closely controlled by the government than in democratic states (Englander et al. 1986). Thus, the role of the next constructivist factor, namely, the political and economic system that diversifies the role of the media in society, is emphasized.

In addition to what was aforementioned, the political context is considered by defining the role of public authorities in shaping the perception of flood risk, including defining the confidence in authorities and public flood protection measures and the associated sense of self-responsibility for risk mitigation activities. The conviction that the authorities bear the main responsibility for flood protection thus removes this burden from residents and is confirmed by Bichard and Kaźmierczak (2012) and by Terpstra and Gutteling (2008). As shown by Grothmann and Reuswig (2006), reliance on public flood protection has resulted in not taking flood control measures. Similarly, Hung (2009) and Terpstra (2011) state that the confidence in public flood protection decreases with the increase in residents' preparedness and willingness to acquire insurance, and according to Bubeck et al. (2012), the actions of the authorities can be an obstacle to taking private mitigation measures. One such example is protection in the form of levees, which provides an apparent sense of security (the socalled "levee effect") to the inhabitants of flood plains. This perception results in the underestimation of flood risk and inhibition of activities toward proper protection against floods (Burton Cutter 2008; Terpstra 2009; Kousky Kunreuther 2009; Ludy Kondolf 2012). Notably, trust in the authorities becomes important in the case of low individual knowledge of the threat (Kellens et al. 2013; Wachinger et al. 2013). Trust in flood protection measures (the belief in their effectiveness) often results from previous flood experiences (Wachinger et al. 2013; Birkholtz et al. 2014).

The cultural context in the study of flood risk perception is considered by Armas et al. (2015), who conduct ethnographic research. Cultural conditions of the studied community constitute the background and complementation of the interpretation of the obtained psychometric results. With a small number of empirical studies on the cultural context published from 2008 to 2018, we must mention the earlier works on cultural values in risk assessment in relation to various types of threats. For example, Rohmann (1994) shows that risk assessments differ significantly in orientation (technological, monetary, environmental, and feminist). In other studies, the phenomena of "cross-cultural, cross-gender reversal" or the dependence of the impact of gender on the level of risk 
perception are considered. The assessment of risk perception of women in Japan and men in the United States was similar (Kleinhesselink Rosa 1991). Gender as a variable plays a greater role in countries with more marked legal and cultural differences between the genders than those that do not.

The historical element (apart from the direct experience of flooding) in contemporary studies of flood risk perception is explored in Działek et al. (2013a, b), who underline the impact of the historical paths of the studied area on the strength of social bonds and type of social capital, and hence the indirect experience, on flood risk perception.

The problem of the influence of religion on the perception and attitudes toward flood risk was analyzed by Schmuck (2000) in the Muslim community, confirming the existence of this dependence in the studied group. In the analyzed community, the conviction that the flood is the work of Allah led to abandoning all actions aimed at the preparedness and mitigation of flood risks. Similarly, in Bustillos Ardaya et al. (2017), Brazilian respondents, when asked why private precautions were not taken, answered: "Whatever God's will is, it will happen," "whenever He wants to take me, it is because it is my time," or "it is not possible to know the intentions of the Lord." In this context, the importance of fatalism, wishful thinking, and hopelessness related to religion in shaping attitudes toward risk is clear. In the protection motivation theory on flood risks by Grothmann and Reusswig (2006), fatalism and denial are among the nonprotective reactions resulting from an inadequate assessment of handling the risk (e.g., response efficacy, self-efficacy, and response costs) with a simultaneous high-risk assessment. This approach to risk concerns people who, through their experience of flooding, are convinced of their inability to control such events. Fatalism, wishful thinking, and denial prevent only the negative emotional consequences of perceived risk, such as fear (Bustillos Ardaya et al., 2017). Notably, the religious and cultural context is also important in the selection of the studied characteristics of the population. For example, in the case of Muslim communities, women are excluded from the study (Oasim et al. 2015).

\section{Discussion, Conclusions And Recommendations}

The abundance of research concerning the level of flood risk perception makes it a dynamic field of empirical research, the resources of which should interest decision makers managing flood risk. The strong diversity of the collected empirical work (e.g., research methods and areas of research) provides a broad view of the applied research approaches.

Rationalists focus on the quantitative approach, probability, and consequences, and constructivists are more interested in the qualitative dimension. The constructivist approach is criticized by researchers for its qualitative character and difficulty in operationalization.

The topics and research interests concerning factors or groups of factors that may influence the perception of flood risk varied over time. In the beginning, attention was paid to the rationalistic approach (mainly to direct experience, socioeconomic and demographic profiles, and information, and later also to residence characteristics and individual's physical location). Over time, the amount of constructivist research increased, particularly that related to indirect experience and a political context. Research interests and their variations over time could result from the availability of data and development of research tools. For example, it is much easier to obtain (and measure) metric information on respondents (e.g., age, gender, education) than their more intimate (personal) data, such as religion and relationships with family or neighbors, and that on historical and cultural backgrounds. With the development of geographical information systems, the scope, detail, and availability of data increased, including techniques for delimiting flood zones, flood characteristics, identification of an individual's physical location, and residence characteristics.

The choice of factors for the perception of flood risk is often simply a matter of interest of an individual researcher. It may also be determined by the research results of other literature due to the easiness of the later discussion on the results obtained. This reasoning can sometimes become a mechanism of a "selfwinding circle," resulting in the excessive expansion of one sphere of research at the expense of another.

Contemporary empirical works on flood risk perception are dominated by a rationalistic approach that psychometrically searches for cognitive models of behaviors when there is flood risk; however, this creates a heterogeneous field of research in terms of basic theoretical issues, methodology, and more importantly, the results obtained. Often, statistically obtained dependencies are mutually exclusive. Physical, cognitive, behavioral, and demographiceconomic variables alone cannot adequately explain attitudes toward flood risk. One limitation of some rationalistic studies is the "flattening" of variables or the inability to consider them because of external factors. For example, in the case of a location variable, there was a high degree of homogeneity, which resulted in lowering the importance of this variable in the results. The exclusion of women from the study of Muslim communities resulted from cultural and religious factors.

Thus, studies on perception in the constructivist approach are at an early stage of development. Currently, they are only a supplement to rationalistic research and not a mainstream tendency in the field of flood risk perception. However, the results of studies of flood risk assessment by the public in a social, political, cultural, religious, or historical context provide a clear picture.

The analysis of the collected empirical works also indicates mutual relations between individual factors of a rationalistic and constructivist nature. Most often, the influence of rationalistic factors results from constructivist conditions. For example, media coverage contributes to the perception of risk mainly when a recipient has no personal direct experience of the flood; other people's experiences (e.g., the effects of the flood experienced by friends, relatives, neighbors, and other people) have a weaker impact on the perception of risk. Trust in the authorities becomes more important when there is little individual knowledge of risk, and trust in flood protection measures (confidence in their effectiveness) often results from the previous experience of flooding. Furthermore, gender plays a greater role in shaping the perception of flood risk in countries where legal and cultural differences between the sexes are more visible.

Moreover, within the group of constructivist factors, some relations can be observed. Information provided at the local level (from neighbors, family, and friends) is more important in developing the risk perception than the institutional impact is. The political and economic system makes the role of the media in

Page $12 / 23$ 
society different (greater control of the authorities results in a more limited amount information on risks). Different historical backgrounds influence the power of social bonds and the type of social capital, shaping the role of indirect experiences in flood risk perception.

The results of this study show a slow shift toward research on soft flood risk perception factors, conducted in the constructivist approach. This is because the role of soft factors in shaping flood risk perception is increasingly important. The greater population mobility causes the mixing of cultures and religions and modification (loosening) of social ties. In the era of a digital information society, the role of media is increasingly important.

Some constructivist factors, such as the influence of media or neighbors, friends, and family on flood risk perception, are more controllable than rationalistic factors (e.g., direct experience of flooding, or gender or age). Constructive studies therefore provide more useful information for improving flood risk management.

Notably, the development of civilization has changed the sources of information about threats, which should be reflected in the research on risk perception. The level of knowledge of risk should not be determined solely based on the knowledge of flood hazard maps, but also, and perhaps primarily, on the basis of media coverage.

Therefore, in the practice of flood risk management, particular attention should be paid to the role of social media in shaping attitudes toward risk. According to the availability heuristic, people remember the hazards that are more dramatically and spectacularly presented better than those that have occurred. In the era of a digital society, electronic media might be more effective in communicating risk. Neighborly ties, by contrast, are loosening up and will be of minor importance in determining the role of indirect experience in shaping attitudes toward risk. It is worth noting the potential of using artificial intelligence (Al) to study the perception of flood risk based on social data. Since it is possible to profile people based on their social network entries, it is also possible to find some common characteristics for groups of people who are more resistant or vulnerable to flood risk based on such networks.

The important information on flood risk management that can be derived from this work is that the influence of rationalistic factors on the level of flood risk perception often results from the constructivist context. Thus, knowing specific local political, cultural, historical, religious, and social conditions makes it possible to more effectively moderate the attitudes of the inhabitants toward flood risks.

The importance of the context in the research on the perception of flood risk has slowly begun to be recognized in the reviews. For example, Raska (2015) perceives the causes of differences in the perception of environmental hazards (e.g., flood risk) occurring between residents of Western Europe and Central and Eastern Europe in different political and cultural contexts (historically conditioned). The post-communist political system (once ensuring a strong position of central government bodies) of the countries of Central and Eastern Europe shape the current passive attitude of the communities of these countries toward floods. In societies of Central and Eastern Europe, decentralized and liberalized as a result of systemic transformation, prevailing materialistic orientation causes greater anxiety and awareness of environmental threats than for the citizens of Western European countries with a post-materialist orientation. Moreover, Boholm (1998) reviews the results of international research draws attention to their diversity, which may result from different geographical, national, and cultural contexts of the studied countries.

In conclusion, constructivist research points to the moderating role of context in studies of flood risk perception. Constructivist factors weaken or strengthen the impact of rationalistic factors on the level of flood risk perception in general and on its three aspects: preparedness, fear, and awareness. A constructivist approach to studying flood risk perception can deepen the understanding of the various, often antagonistic, results of rationalistic research.

The research on flood risk perception should be reoriented. Because of the low compliance of the results of rationalistic research, manifested by the unclear influence of physical, cognitive, behavioral, and demographic-economic factors on flood risk perception, the focus of flood risk research should be shifted to studying the role of contextual factors in shaping risk perception. It is necessary to assess how the public interprets flood risks socially and culturally, and not merely in terms of metric data. The study of risk perception is a social study; thus, the specifics of the studied society (its worldview, culture, history) should be considered. According to ethnographers, human social existence is culturally variable. Perceptions of events and phenomena are conditioned by values that differ locally. Brikholtz et al. (2014) express the same opinion and agree with the need to comprehensively reinvigorate flood risk research, supported by a more constructive approach to flood risk management. Tierney (1999) argues for the use of a constructivist approach by saying that it provides mechanisms by which specific risk perception can be disseminated and legitimized at a wider social level.

However, complete disregard for the rationalist approach is not possible in studies of flood risk perception. Notably, the constructivist and rationalist perspectives are insufficiently reliable and credible. As Renn (1989) aptly points out, they are unable to provide solid guidance on their own, and public values, rational decision-making, and scientific knowledge should be reconciled through a "well-managed discourse."

In connection with the above, there is a need to revive the study of flood risk perception toward a more holistic view, namely, the development of a constructivist approach to provide a more comprehensive understanding of the factors affecting the perception of flood risk. The constructivist paradigm therefore recommends a more comprehensive analysis of how the socio-cultural context shapes a broader understanding of risk. Research teams should include geographers and scientists representing other scientific disciplines, such as psychology, sociology, cultural studies, religious studies, ethnography, political science, history, social communication, and media.

The postulated direction of flood risk research is part of the research concepts of vulnerability, capacity, and resilience. It closely refers to the innovative approach to developing a social resilience model, which would be based, among other things, on the perception of flood risk (Bradford et al, 2012). The concept of resilience assumes a positive adaptation of society to the existing developmental threats. A resilient society is one that adapts continuously and flexibly to changing circumstances. Community resilience has been highlighted as one of four priority mechanisms for disaster risk reduction worldwide (Schelfaut et al., 2011). The role of risk perception in improving the resilience of people and communities is widely recognized as an important part of the wider area of risk research (Burns, Slovic, 2012). Risk perception is often viewed as a key element of vulnerability assessment.

Page $13 / 23$ 
In many studies, the perception of risk is considered a factor of vulnerability (e.g., Messner and Meyer, 2006; Kuhlicke et al., 2011), but we can agree with Brikholtz et al. (2014) that they rarely elaborate on the perception of flood risk in a substantive manner. Some resilience studies often consider the important role of risk perception as an argument for better risk communication in flood management strategies (e.g., Schelfaut et al., 2011). However, based on the literature on flood risk management, the perception of Kuhlicke and Steinführer (2013) is that the concept of resilience is largely in its infancy, and we agree. At present, relatively few empirical studies have examined the perception of flood risk in terms of resilience. The statement in Brikholtz et al. (2014, p. 15) that the concept of resilience "should, we argue, be used to greater effect in underpinning flood risk research" exactly corresponds to the recommendations made in this work regarding a renewed research agenda for flood risk perception.

\section{Declarations}

Funding: This work was supported by the National Science Centre [grant DEC-2011/03/N/HS4/00436].

The author has no relevant financial or non-financial interests to disclose.

The author has no conflicts of interest to declare that are relevant to the content of this article.

The author certifies that she has no affiliations with or involvement in any organization or entity with any financial interest or non-financial interest in the subject matter or materials discussed in this manuscript.

The author has no financial or proprietary interests in any material discussed in this article.

\section{References}

1. Armaş I, and Avram E (2008) Patterns and trends in the perception of seismic risk. Case study: Bucharest Municipality/Romania. Nat Hazards 44 (1):147-161

2. Armas I, lonescu R, Posner C N (2015) Flood risk perception along the Lower Danube river, Romania. Nat Hazards 79:1913-1931

3. Baan P J A, Klijn F (2004) Flood risk perception and implications for flood risk management in the Netherlands. Int J River Basin Manag 2(2):1-10

4. Barnett J, Breakwell G. M. (2001) Risk perception and experience: Hazard personality profiles and individual differences. Risk Anal 21 (1):171-177

5. Becker G, Aerts J C J H, Huitema D (2013) Influence of flood risk perception and other factors on risk-reducing behaviour: a survey of municipalities along the Rhine. J Flood Risk Manag 7(1):16-30

6. Bera M K, Daněk P, (2018) The perception of risk in the flood-prone area: a case study from the Czech municipality. Disast Prev Manag 27(1):2-14

7. Bichard E, Kazmierczak A (2012) Are homeowners willing to adapt to and mitigate the effects of climate change? Clim Chang 112:633-654

8. Biernacki W, Bokwa W, Działek J, Padło T (2009) Społeczności lokalne wobec zagrożeń przyrodniczych i klęsk żywiołowych. Instytut Geografii i Gospodarki Przestrzennej Uniwersytetu Jagiellońskiego Kraków

9. Birkholz S, Muro M, Jeffrey P, Smith H M (2014) Rethinking the relationship between flood risk perception and flood management. Sci Total Environ 478:12-20

10. Boholm A (1998) Comparative studies of risk perception: a review of twenty years of research. J Risk Res 1(2):135-163

11. Botzen W J W, van den Bergh J C J M (2012) Monetary valuation of insurance against flood risk under climate change. Int Econ Rev 53(3):1005-1026

12. Botzen W J W, Aerts J C J H, van den Bergh J C J M (2009b) Willingness of homeowners to mitigate climate risk through insurance. Ecol Econ 68:22652277

13. Botzen W J W, Aerts J C J H, van den Bergh J C J M (2009a) Dependence of flood risk perceptions on socioeconomic and objective risk factors. Water Resour Res 45 doi:10.1029/2009WR007743

14. Bradford R A, O'Sullivan J J, van der Craats I M, Krywkow J, Rotko P, Aaltonen J, Bonaiuto M, De Dominici S, Waylen K, Schelfaut K (2012) Risk perception - issues for flood management in Europe. Nat Hazards Earth Syst Sci 12:2299-2309

15. Bubeck P, Botzen W J W, Aerts, J C J H (2012) A Review of Risk Perceptions and Other Factors that Influence Flood Mitigation Behavior. Risk Anal 32(9):1481-1495

16. Burningham K, Fielding J, Thrush D (2008) "It'll never happen to me": Understanding public awareness of local flood risk. Disasters 32(2):216-238

17. Burns W J, Slovic P (2012) Risk perception and behaviors: anticipating and responding to crises. Risk Anal 32:579-82

18. Burton C, Cutter S (2008) Levee failures and social vulnerability in the Sacramento-San Joaquin Delta Area, California. Nat Hazards Rev 9 (Special issue: Flooding in the Central Valley) 136-149

19. Burton I, Kates R ., Mather J R, Snead R E, (1965) The shores of megalopolis: coastal occupance and human adjustment to flood hazard. Publications in climatology 18 (3).

20. Bustillos Ardaya A, Evers M, Ribbe L (2017) What influences disaster risk perception? Intervention measures, flood and landslide risk perception of the population living in flood risk areas in Rio de Janeiro state, Brazil. Int J Disaster Risk Reduct 25:227-237

21. Clarke L, Short J F(1993) Social organization and risk: some current controversies. Annu Rev Sociol 19:375-399

22. Colten C E, Sumpter A R (2009) Social memory and resilience in New Orleans. Nat Hazards 48(3):355-364

23. Cutter S L, Boruff B J, Shirley W L (2003) Social vulnerability to environmental hazards. Soc Sci Q 84:242-261 
24. Dake K (1991) Orientating dispositions in the perceptions of risk: an analysis of contemporary worldviews and cultural biases. J of Cross-Cult Psychol 22:61-82

25. De Marchi B (2007) Flood risk management with the public. Proceedings of the European Symposium on Flood Risk Management Research pp. $153-154$. Istituto di Sociologia Internazionale di Gorizia

26. Douglas M (1978) Cultural bias. Occasional Paper no. 35. Royal Anthropological Institute of Great Britain and Ireland, London

27. Douglas M. (1992) Risk and Blame. Routledge London

28. Douglas M, Wildavsky A B (1982) Risk and culture: an essay on the selection of technical and environmental dangers. Berkeley University of California Press

29. Drake K (1992) Myths of nature: culture and the social construction of risk. J Soc Issues 48(4):21-37

30. Duží B, Vikhrov D, Kelman I, Stojanov R, Juřička D (2015) Household measures for river flood risk reduction in the Czech Republic. J Flood Risk Manag doi.10.1111/jfr3.12132

31. Działek J, Biernacki W, Bokwa A (2013a) Challenges to social capacity building in flood-affected areas of southern Poland. Nat Hazards Earth Syst Sci 13:2555-2566

32. Działek J, Biernacki W, Bokwa A (2014) Impact of Social Capital on Local Communities' Response to Floods in Southern Poland In: Neef A, Shaw R (ed.) Risks and Conflicts: Local Responses to Natural Disasters (Community, Environment and Disaster Risk Management, Volume 14) Emerald Group Publishing Limited, pp.185 - 205

33. Englander T, Farago K, Slovic P A (1986) Comparative analysis of risk perception in Hungary and the United states. Soc Behav 1:55-66

34. Finucane M L, Alhakami A, Slovic P, Johnson S M (2000) The affect heuristic in judgments of risks and benefits. J Behav Decis Making 13:1-17

35. Fischhoff B, Slovic P, Lichtenstein S, Read S, Combs B (1978) How Safe is Safe Enough - Psychometric Study of Attitudes towards Technological Risks and Benefits. Policy Sci 9(2):127-152

36. Fitton S L, Moncaster A, Guthrie P (2015) Investigating the social value of the Ripon rivers flood alleviation scheme. J Flood Risk Manag doi $10.1111 / \mathrm{jfr} 3.12176$

37. Flynn J, Slovic P, Mertz C K (1994) Gender, race and environmental health Risk Anal 14:1101-1108

38. Goszczyńska M, Tyszka T, Slovic, P. (1991) Risk perception in Poland: a comparison with three other countries. J Beha Deci Mak 4:179-193

39. Grothmann T, Reusswig F (2006) People at risk of flooding: Why some residents take precautionary action while others do not. Nat Hazards 38(1-2):101120

40. Gustafson P E (1998) Gender Differences in Risk Perception: Theoretical and Methodological Perspectives. Risk Anal 18(6):805-811

41. Harries T, Penning-Rowsell E (2011) Victim pressure, institutional inertia and climate change adaptation: The case of flood risk. Glob Environ Change 21:188-197

42. Heitz C, Spaeter S, Auzet A V, Glatron S (2009) Local stakeholders' perception of muddy flood risk and implications for management approaches: A case study in Alsace (France). Land Use Policy 26:443-451

43. Hilgartner S (1992) The social construction of risk objects. In Short J F, Clarke L (eds) Organizations, Uncertainties and Risk pp. $39-53$ Westview Press

44. Ho C, Shaw D, Lin S, Chiu Y C (2008) How do disaster characteristics influence risk perception? Risk Anal 28(3):635-643

45. Hung H C (2009) The attitude towards flood insurance purchase when respondents' preferences are uncertain: a fuzzy approach. J Risk Res 12(2):239258

46. Johnson E J, Tversky A (1983) Affect, generalization, and the perception of risk. J Pers Soc Psychol 45:20-31

47. Johnson J G, Wilke A, Weber E U, (2004) Beyond a trait view of risk-taking: a domain- specific scale measuring risk perceptions, expected benefits, and perceived-risk attitude in German-speaking populations. Polish Psychol Bull 35:153-172

48. Karpowicz-Lazreg C, Mullet E (1993) Societal risk as seen by the French public. Risk Anal 13:253-258

49. Kates R W (1963) Perceptual regions and regional perception in floodplain management. Papers and proceedings of the Regional Science Association $11: 217-227$

50. Kellens W, Terpstra T, Schelfaut K, De Maeyer P (2013) Perception and communication of flood risks: A literature review. Risk Anal 33(1):24-49

51. Kellens W, Zaalberg R, Neutens T, Vanneuville W, De Maeyer P (2011) An Analysis of the Public Perception of Flood Risk on the Belgian Coast. Risk Anal 3 (7):1055-1068

52. Keown C F (1989) Risk perceptions of Hong Kongese vs. Americans, Risk Anal 9:401-405.

53. King D (2000) You're on our own: community vulnerability and the need for awareness and education for predictable natural disasters. J Conting Crisis Man 8:223-228

54. Kleinhesselink R R, Rosa E A (1991) Cognitive representations of risk perceptions: a comparison of Japan and the United J Cross-Cult Psychol 22:11-28

55. Kleinhesselink R R, and Rosa E R (1994) Nuclear trees in a forest of hazards: a comparison of risk perceptions between American and Japanese university In Lowinger C, Hinman G W (eds) Nuclear Power at the Crossroads: Challenges and Prospects for the Twenty-first Century pp. 101-119 International Research Center for Energy and Economic Development, Washington State University

56. Knocke E T, Kolivras K N (2007) Flash flood awareness in south west Virginia. Risk Anal 27(1):155-169

57. Kousky C, Kunreuther H (2009) Improving flood insurance and flood risk management: insights from St. Louis, Missouri. Res Future RFF DP 09-07:1-34 
58. Kreibich H, Seifert I, Thieken AH, Lindquist E, Wagner K, Merz B (2011) Recent changes in flood preparedness of private households and businesses in Germany. Reg Environ Change 11:59-71

59. Kreibich H, Thieken A H, Petrow T, Müller M, Merz B (2005) Flood loss reduction of private households due to building precautionary measures: Lessons learned from the Elbe flood in August 2002. Natl Hazards and Earth Syst Sci 5:117-126

60. Kuhlicke C, Steinführer A, (2013) Searching for resilience or building social capacities for flood risks? Planning Theory Pract 14/1:114-20

61. Kuhlicke C, Steinführer A, Begg C, Bianchizza C, Bründl M, Buchecker M (2011) Perspectives on social capacity building for natural hazards: outlining an emerging field of research and practice in Europe. Environ Sci Pol 14:804-14

62. Kunreuther H (1996) Mitigating disaster losses through insurance. J Risk Uncertainty 12:171-187

63. Lamond J E, Proverbs D G, Hammond F N (2009) Accessibility of flood risk insurance in the UK: confusion, competition and complacency. J Risk Res 12(6):825-841

64. Lechowska E (2018) What determines flood risk perception? A review of factors of flood risk perception and relations between its basic elements. Nat Hazards 94(3): 341-1366

65. Lichtenstein S, Slovi P, Fischhoff B, Layman M, Combs B (1978) Judged frequency of lethal events. J Exp Psychol Learn Mem Cogn 4:551-578

66. Lindell M K, Hwang S N (2008) Household's perceived personal risk and responses in a multihazard environment. Risk Anal 28(2):539-556

67. Ludy J, Kondolf G M (2012) Flood risk perception on lands 'protected' by 100-year Levees. Nat Hazards doi.10.1007/s11069-011-0072-6

68. Messner F, Meyer V (2006) Flood damage, vulnerability and risk perception - challenges for flood damage research. In: Schanze J, Zeman E, Marsalek J

(eds) Flood Risk Management - Hazards, Vulnerability and Mitigation Measures. Nato Science Series IV pp. 149-167 Springer

69. Miceli R, Sotgiu I, Settanni M (2008) Disaster preparedness and perception of flood risk: A study in an alpine valley in Italy. J Environ Psychol 28(2):164173

70. Morgan MG, Fischhoff B, Bostrom A, Atman C . (2001) Risk Communication: A Mental Models Approach. Cambridge University Press Cambridge

71. O'Neill E, Brereton F, Shahumyan H, Clinch J P (2016) The Impact of Perceived Flood Exposure on Flood-Risk Perception: The Role of Distance. Risk Anal 36(11): 2158-2186

72. Oasim S, Khan A N, Shrestha R P, Qasim M (2015) Risk perception of the people in the flood prone Khyber Pukhthunkhwa province of Pakistan. Int J Disaster Risk Reduct 14:373-378

73. Oliver-Smith A (1996) Anthropological research on hazards and disasters. Annu Rev Anthropol 25:303-328

74. Otway H J, von Winterfeldt D (1982) Beyond acceptable risk: on the social acceptabilities of technologies. Policy Sci 14:247-256

75. Pagneux E, Gísladóttir G, Jónsdóttir S (2011) Public perception of flood hazard and flood risk in Iceland: A case study in a watershed prone to ice-jam floods. Nat Hazards 58:269-287

76. Poortinga W, Bronstering K, Lannon S (2011) Awareness and perceptions of the risks of exposure to indoor radon: A population based approach to evaluate a radon awareness and testing campaign in England and Wales. Risk Anal 31:1800-1812

77. Poumadere M, Mays C, Slovi, P, Flynn J, Johnson S (1995) What lies behind public acceptance? Comparison of US and French perceptions of the nuclear power option. In: The International Atomic Energy Agency, Proceedings series. International conference on the nuclear power option pp. 393-405 Vienna

78. Poussin J, Botzen W W, Aerts J C (2014) Factors of influence on flood damage mitigation behaviour by households. Environ Sci Policy 40:69-77

79. Raaijmakers R, Krywkow J, van der Veen A (2008) Flood risk perceptions and spatial multi-criteria analysis: an exploratory research for hazard mitigation. Nat Hazards 46(8):307-322

80. Raska P (2015) Flood risk perception in Central-Eastern European members states of the EU: a review. Nat Hazards 79:2163-2179

81. Rayner S, Cantor R (1987) How fair is safe enough. The cultural approach societal technology choice. Risk Anal 7:3-9

82. Renn $O$ (1989) Risikowahrnehmung - psychologische Determinantenbei der intuitive Erfassung und Bewertung von technischen Risiken. In Eberhard $F$ (ed) Risiko in der Industriegesellschaft: Analyse Vorsorge, Akzeptanz pp. 167-182. Erlangen

83. Rohrmann, B (1994) Risk perception of different societal groups: Australian findings and cross-national comparison. Austral J Psychol 46:150-163

84. Schelfaut K, Pannemans B, van der Craats I, Krywkow J, Mysiak J, Cools J (2011) Bringing flood resilience into practice: the FREEMAN project. Environ Sci Pol 14:825-33

85. Scheue, S, Haase D, Meyer V (2011) Exploring multicriteria flood vulnerability by integrating economic, social and ecological dimensions of flood risk and coping capacity: from a starting point view towards an end point view of vulnerability. Nat Hazards 58(2):731-751

86. Schmuck H (2000) "An Act of Allah": religious explanations for floods in Bangladesh as survival strategy. Int J Mass Emerg Disasters 18(1):85-96

87. Shaw R, Shiwaku K, Kobayashi H, Kobayashi M (2004) Linking experience, education, perception and earthquake preparedness. Disast Prev Manag 13(1):39-49

88. Short J F, (1984) The social fabric of risk: toward the social transformation of risk analysis. Am Sociol Rev 49:711-725

89. Short J F, Jr Clarke L (eds) (1992) Organizations, Uncertainties and Risk. Westview Press Boulder

90. Siegrist M, Gutscher H (2008) Natural hazards and motivation for mitigation behavior: People cannot predict the affect evoked by a severe flood. Risk Anal 28:(3):771-778

91. Sjöberg L (1996) A discussions of the limitations of the psychometric and cultural theory approaches to risk perception. Radiat Prot Dosim 68:219-225

92. Sjöberg L (1998) Worry and risk perception. Risk Anal 18:85-93

93. Slovic P (1987) Perception of Risk. Science 236(4799):280-285

Page $16 / 23$ 
94. Slovic $P$ (2000) The perception of risk. Earthscan London

95. Slovic P, Finucane M L, Peters E, Mac Gregor D G (2004) Risk as analysis and risk as feelings: Some thoughts about effect, reason, risk and rationality. Risk Anal 24(2):311-322

96. Slovic P, Fischhoff B, Lichtenstein S (1980) Facts and fears: understanding perceived risk. In Schwing R C, Alberts W A Jr (eds) Societal Risk Assessment: How Safe is Safe Enough? pp. 181-216 Plenum Press, New York

97. Stojanov R, Duží B, Daněk ., Němec D, Procházka D (2015) Adaptation to the Impacts of Climate Extremes in Central Europe: A Case Study in a Rural Area in the Czech Republic. Sustainability 7(9):12758-12786

98. Takao ., Motoyoshi T, Sato T, Fukuzono T (2004) Factors determining residents' preparedness for floods in modern megalopolises: The case of the Tokai flood disaster in Japan. . Risk Res 7(7-8):775-787

99. Teigen K H, Brun W, Slovic P (1988) Societal risks as seen by the Norwegian J Behav Decis Making 1:111-130

100. Terpstra T (2009) Flood Preparedness: Thoughts, Feelings and Intentions of the Dutch Public doi: 10.3990/1.9789036529549

101. Terpstra T (2011) Emotions, trust and perceived risk: Affective and cognitive routes to flood preparedness behavior. Risk Anal 31:1658-1675

102. Terpstra T, Gutteling J M (2008) Households' perceived responsibilities in flood risk management in the Netherlands. Int J Water Resour Dev 24:555-565

103. Terpstra T, Lindell M K, Gutteling, J M (2009) Does communicating (flood) risk affect (flood) risk perceptions? Results of a quasi experimental study. Risk Anal 29(8):1141-1155

104. Thieken A H, Kreibich H, Muller M, Merz B (2007) Coping with floods: Preparedness, response and recovery of flood-affected residents in Germany in 2002. Hydrol Sci J 52(5):1016-1037

105. Thieken A H, Petrow T, Kreibich H, Merz B (2006) Insurability and mitigation of flood losses in private households in Germany. Risk Anal 26(2):383-395

106. Thistlethwaite J, Henstra D, Brown C, Scott D (2018) How Flood Experience and Risk Perception Influences Protective Actions and Behaviours among Canadian Homeowners. Environ. Manag 61:197 - 208

107. Thompson M, Ellis R, Wildavsky A (1990) Cultural Theory. Westview Press Boulder

108. Tierney K J (1999) Toward a critical sociology of risk. Sociol Forum 14(2):215-242

109. Tobin G A, Montz B (1997) Natural hazards: Explanation and integration. The Guilford Press, New York

110. Vlek C J H, Stallen, P J M (1981) Judging risks and benefits in the small and in the large. Organ. Behav Hum Perform 28:235-271

111. Wachinger G, Renn O, Begg C, Kuhlicke C (2013) The Risk Perception Paradox-Implications for Governance and Communication of Natural Hazards. Risk Anal 33(6): 1049-1065

112. Weichselgartner J (2001) Disaster mitigation: the concept of vulnerability revisited. Disast Prev Manag 10(2):85-94

113. Werritty A, Houston, D, Ball T, Tavendale A, Black A (2007) Exploring the social impacts of flood risk and flooding in Scotland. Scottish Executive Edinburgh.

114. White G (1945) Human adjustment to floods: a geographical approach to the flood problem in the United States. Research Pape 29 Department of Geography University of Chicago

115. Wildavsky A, Dake K (1990) Theories of risk perception: who fears what and why. Daedalus 119(4):41-60

116. Zaalberg R, Midden C, Meijnders A, McCalley T (2009) Prevention, adaptation, and threat denial: Flooding experiences in the Netherlands. Risk Anal 29(12):1759-1778

117. Zhang Y, Hwang S N, Lindell M K (2010) Hazard proximity or risk perception? Evaluating effects of natural and technological hazards on housing values. Environ Behav 42(5):597-624

\section{Figures}




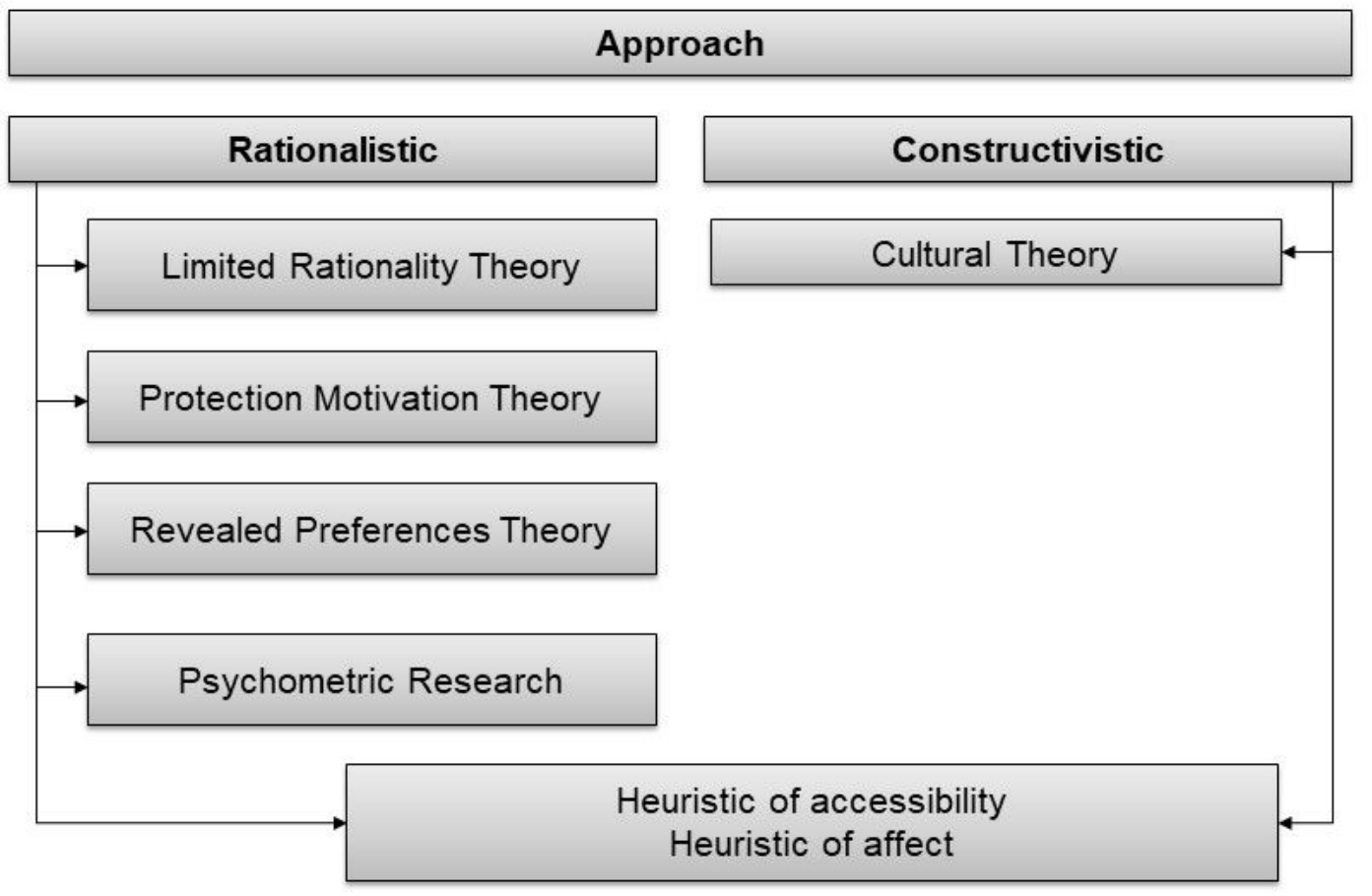

Figure 1

Theories in rationalistic and constructivistic approach 


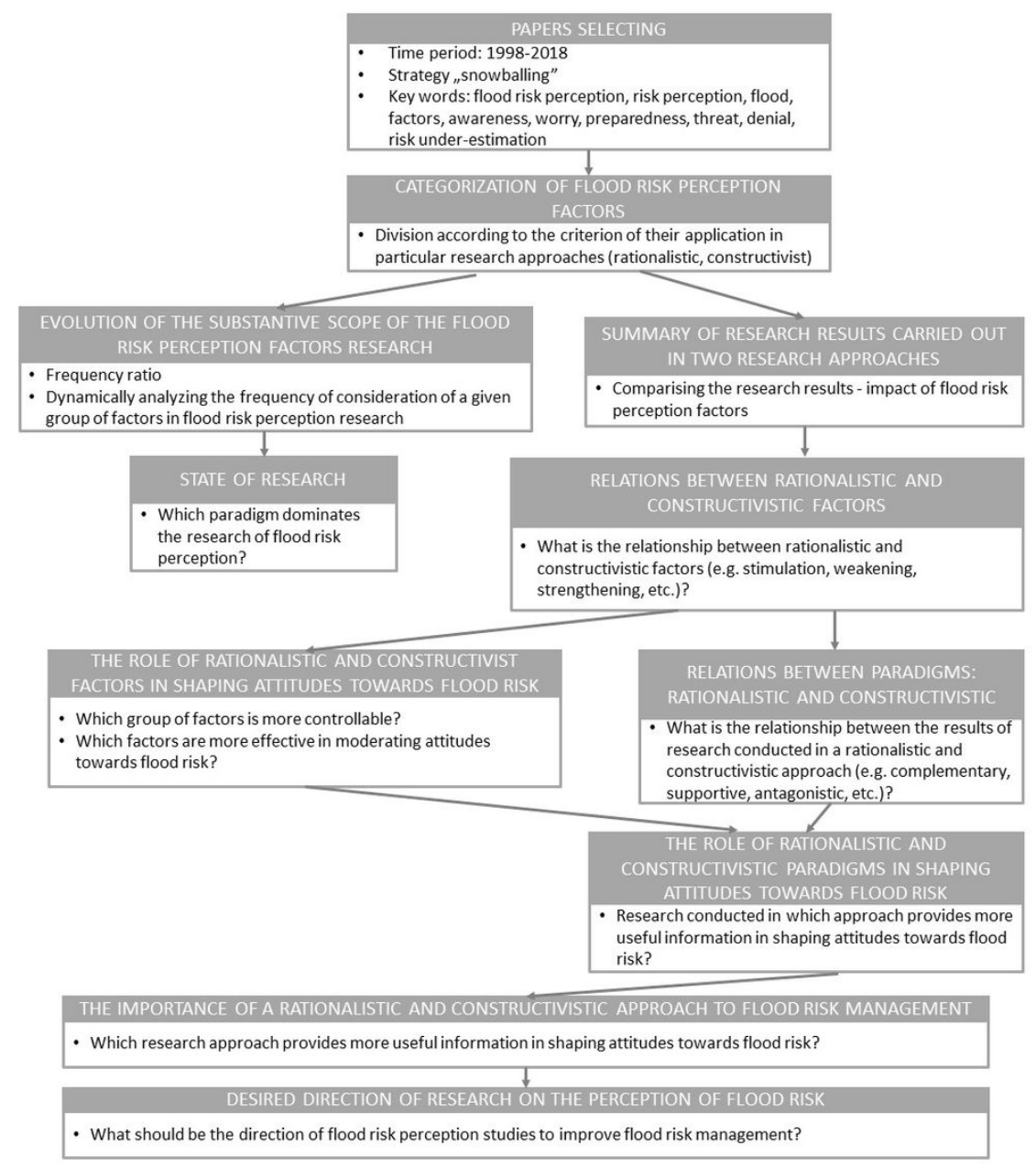

Figure 2

Research design.

Factors

\begin{tabular}{|c|c|c|}
\hline 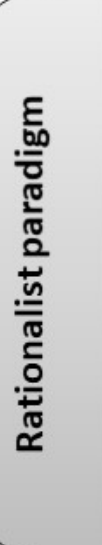 & $\begin{array}{l}\text { - individual's physical location } \\
\text { - } \text { flood characteristics } \\
\text { - } \text { residence characteristics } \\
\text { - } \text { size of consequences } \\
\text { - } \text { range of impact } \\
\text { - direct experience } \\
\text { - } \text { socio-economic and demographic } \\
\text { - information, knowledge }\end{array}$ & $\begin{array}{l}\text { - proximity to a hazard, the probability of the flood } \\
\text { occurrence } \\
\text { - mountain, lowland flood } \\
\text { - owning a house, type of a building, presence } \\
\text { of a ground floor, cellar, lenght of residence } \\
\text { - } \text { flood losses } \\
\text { - the group of people influenced by the flood } \\
\text { - gender, age, education, income, number of } \\
\text { children } \\
\text { the level of hazard awareness and the degree } \\
\text { of its uncertainty }\end{array}$ \\
\hline 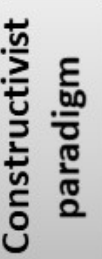 & $\begin{array}{ll}\text { - } & \text { indirect experience } \\
\text { - } & \text { cultural-historical context } \\
\text { - } & \text { religious context } \\
\text { - } & \text { political context }\end{array}$ & $\begin{array}{l}\text { - } \text { friends, familily, neighbors, media } \\
\text { - } \text { culture, history, social bonds } \\
\text { - } \text { religion } \\
\text { - } \text { political system, government policy, trust in } \\
\text { government and public protection measures }\end{array}$ \\
\hline
\end{tabular}

\section{Description}


Figure 3

Categorization of flood risk perception factors.

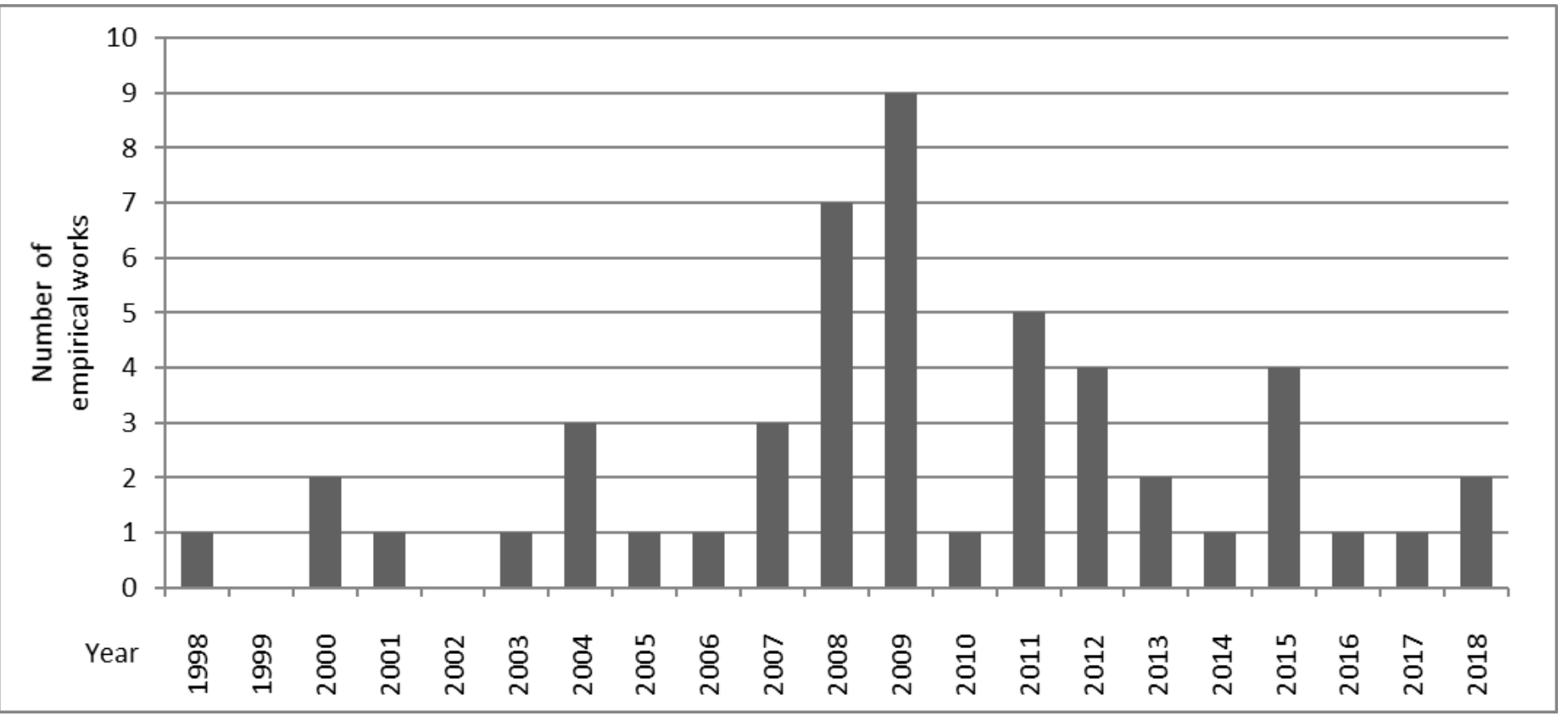

Figure 4

Number of empirical works devoted to the factors of perception of flood risk published from 1998 to 2018.

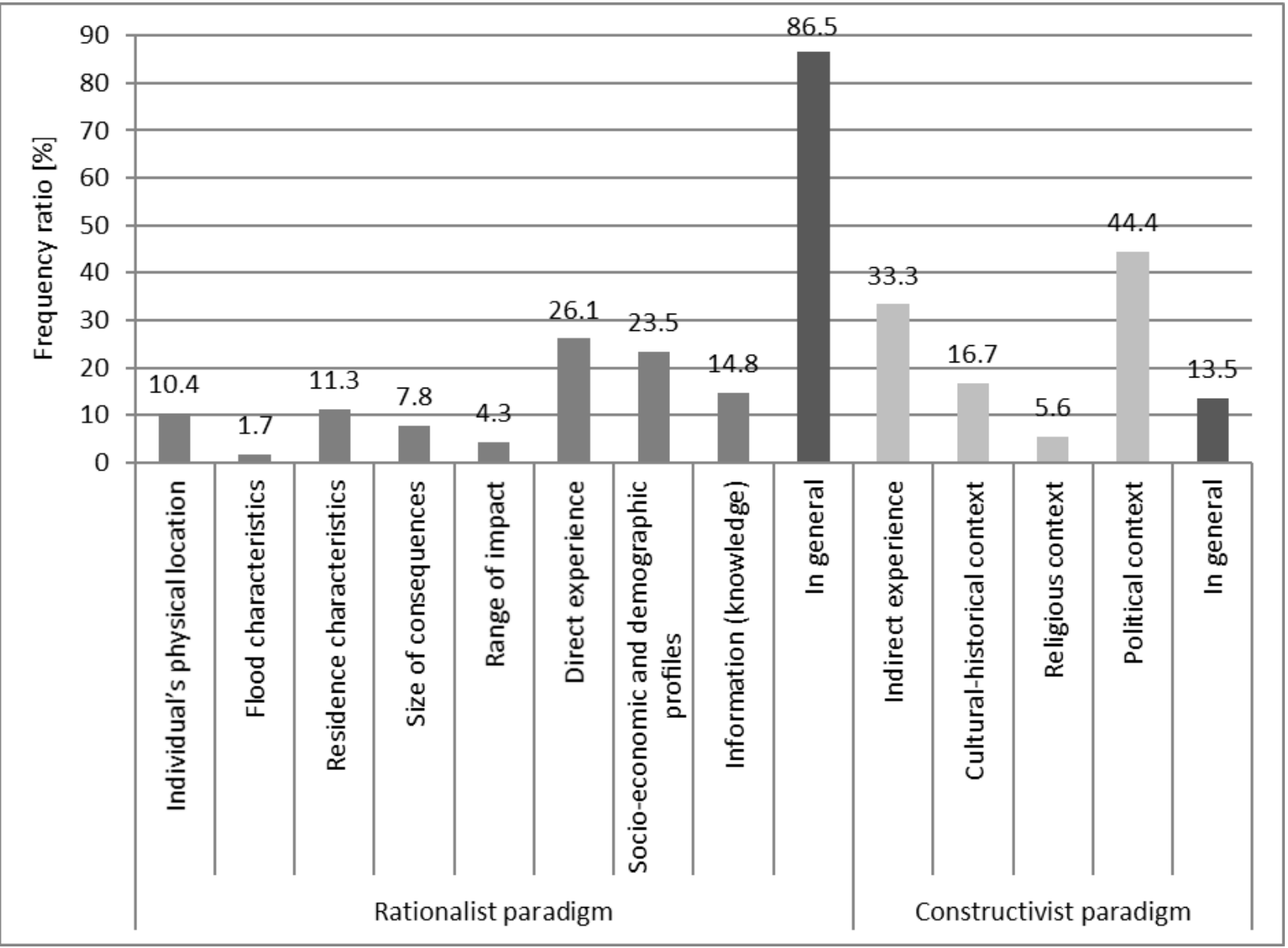

Figure 5

Flood risk perception factors frequency ratio. 


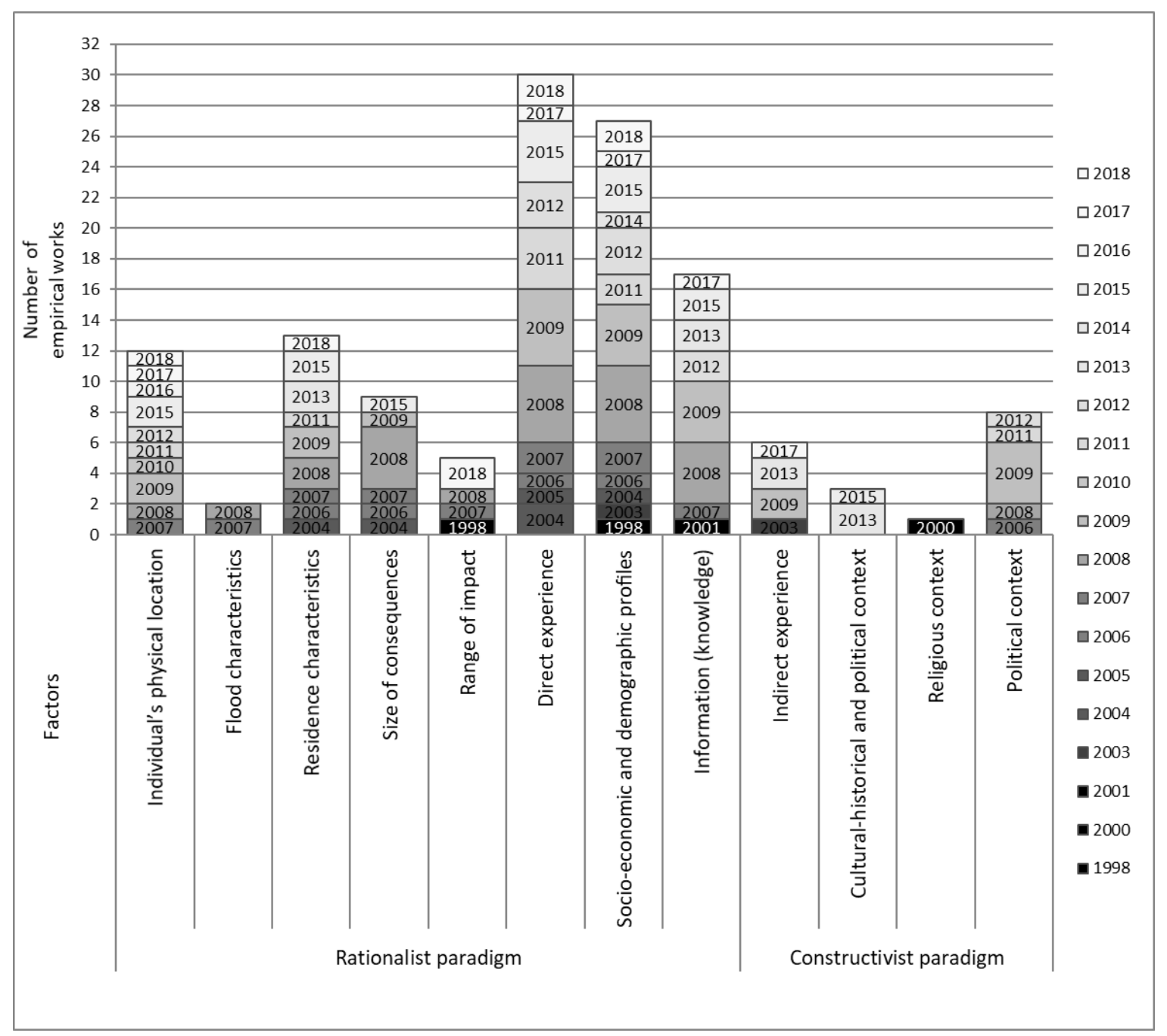

\section{Figure 6}

Number of empirical papers by included factors of flood risk perception published from 1998 to 2018. 


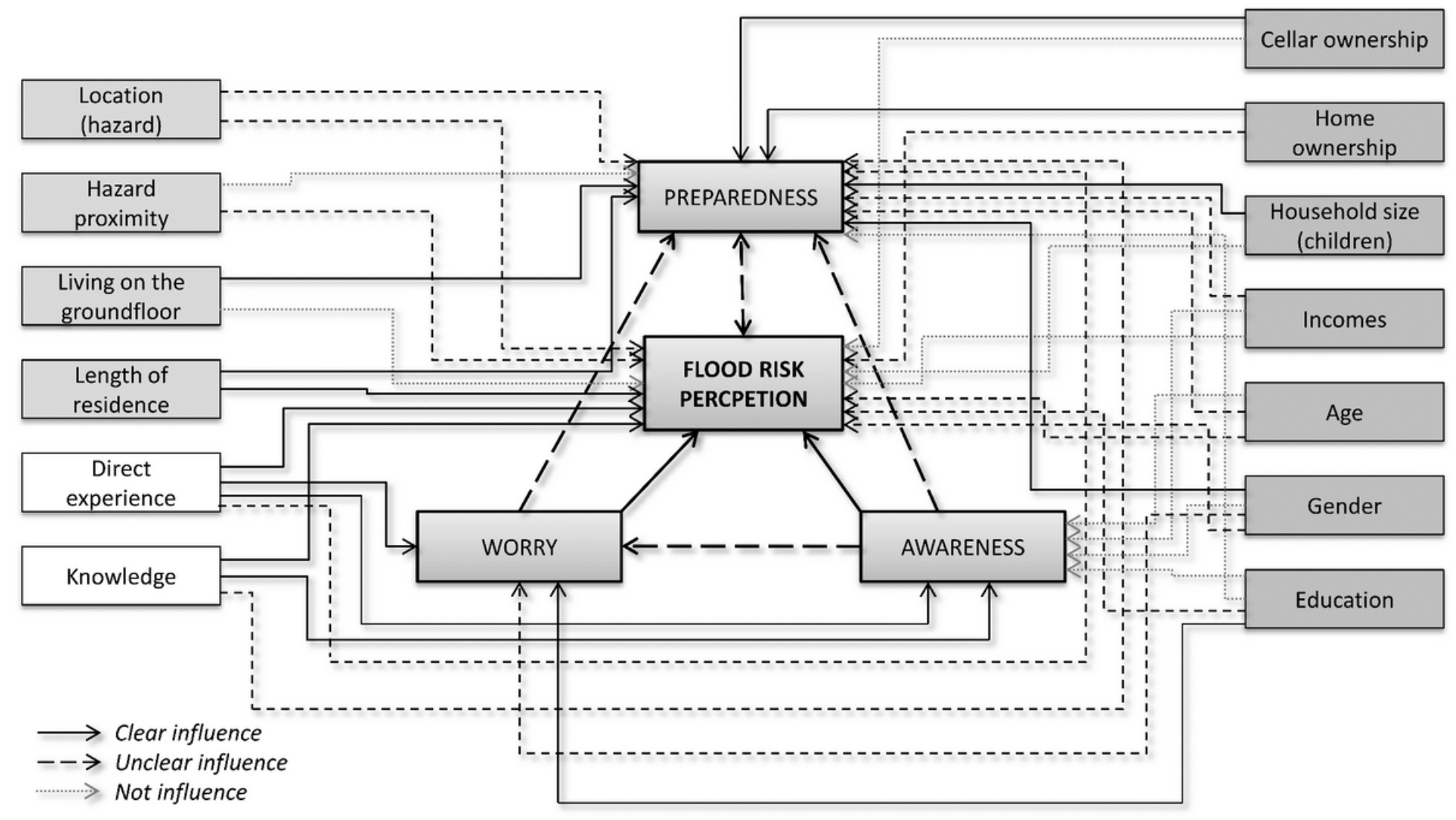

Figure 7

Impact of factors on flood risk perception and its three aspects-a comparison of the results of a rationalist approach.

\section{Clear influence}

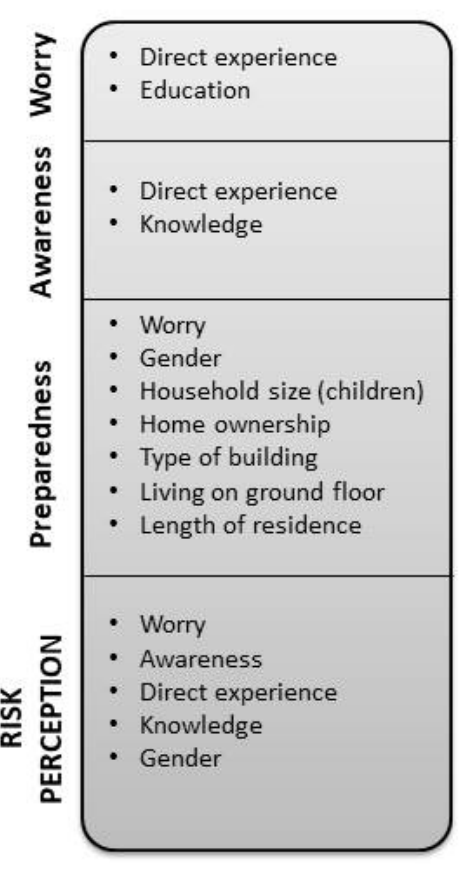

Not influence

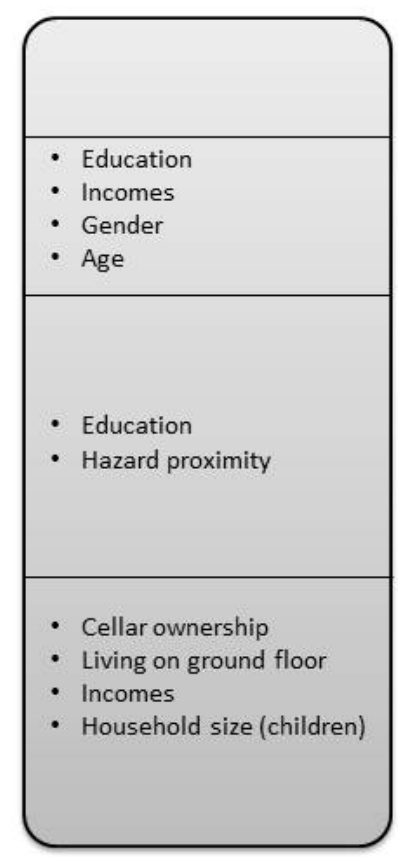

Unclear influence

\begin{tabular}{|l|}
\hline - Awareness \\
\hline Gender \\
\hline - - Awarry \\
\hline - Direct experience \\
- Riskperception \\
- Knowledge \\
- Age \\
- Locomes \\
\hline - Hazardion (hazard) \\
\hline - Location (hazard) \\
- Length of residence \\
- Home ownership \\
- Education
\end{tabular}

Figure 8

Impact of particular factors on the perception of flood risk and on three aspects of flood risk perception-a summary of the results of a rationalist approach. 


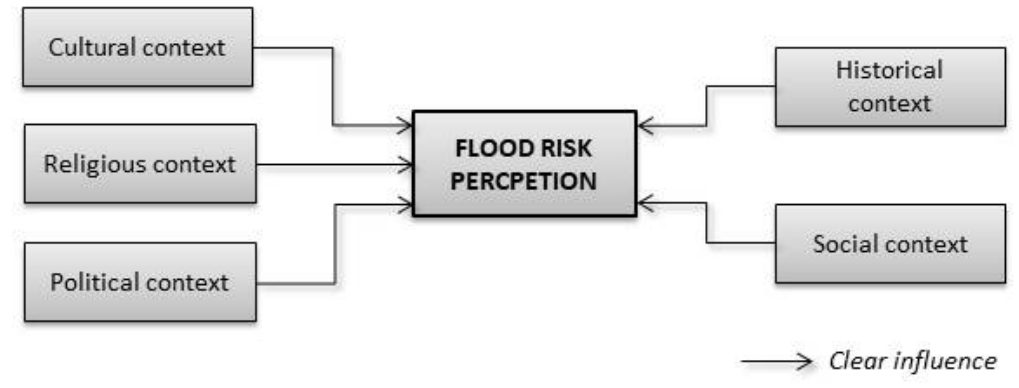

Figure 9

Influence of factors on the perception of flood risk-a summary of the results of the constructivist approach. 